 \\ 岁 PEP III
}

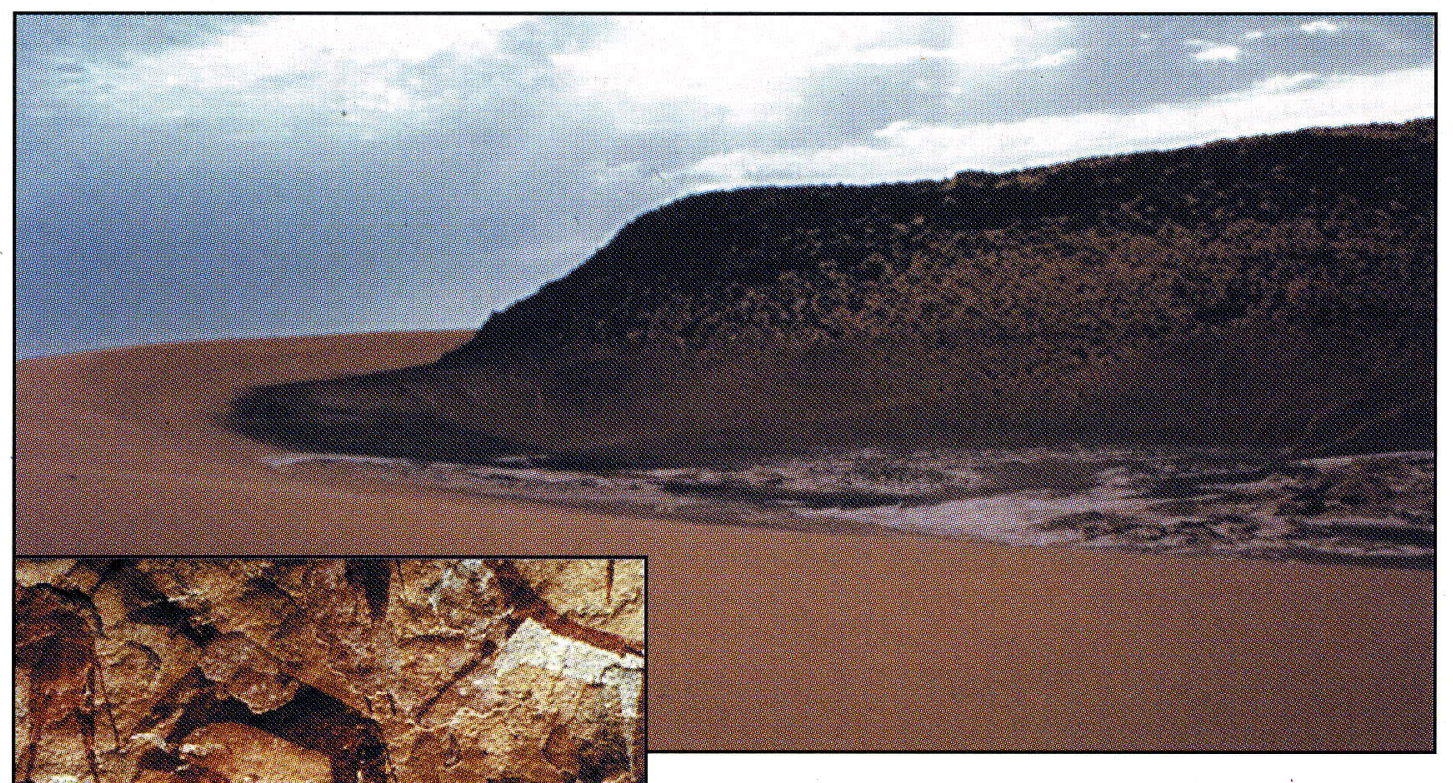

One of the most dramatic responses to climate change along PEP III has been hydrological change in the Sahara-Sahel. The area of the Tin Ouaffadene groundwater-fed paleolake in the Ténéré desert was inhabited 10,000-6000 years ago. (Photo: F. Gasse)

\section{The Paris-Bierville Workshop}

12 - 15 September, 1996

This meeting was supported by IGBP-PAGES, START, the European Science Foundation, the US National Science Foundation, the French CNRS, the INQUA-PAGES Paleomonsoon Project and MEDIAS-FRANCE. It was organized by MEDIAS-FRANCE and the Paleoclimate team of URACNRS, 723 (Orsay, France).

The primary purpose of the Meeting was to stimulate, prioritize and coordinate the work of the leading paleoenvironmental researchers in the region of the PEP III Transect, in line with the intentions set out in the PANASH Project document (PAGES Report, 1995-1). The meeting brought together 78 scientists from 24 countries and was a major landmark in the advancement of the PEP III objectives.

It allowed the PEP III leaders to:

- summarize the state-of-the-art in relation to the major scientific questions posed for PEP III in the PANASH Report and the PAGES Implementation Plan,

- strengthen the development of thematic working groups and establish strategies for improving their efficiency in the area of data acquisition,

- stimulate the further development of regional PEP III coordination committees,

- lay the ground work for ensuring effective data management and integration.

Some thirty oral communications were presented as well as a comparable number of posters. The oral presentations focused on major PEP III objectives and

PEP III: the Paris-Bierville Workshop (F. Gasse)

1996-1997 Activites of CAPE (G. Miller, A. Elverhoi, S. Hicks)

PAGES Calendar

The IMAGES ocean coring and scientific cooperation efforts; Selected results (L. Labeyrie et al.)

\section{1st IGBP PAGES Open Science Meeting}

PACES Scientific Highlight:

The last Glacial Period: rapid changes in air temperature and ocean hydrology (L. Labeyrie, E. Cortijo) 


\section{EDITORIAL}

The main foci of the present Newsletter are the Pole-Equator-Pole Transect that runs through Europe and Africa (PEP III) and the International Marine Global Change Study (IMAGES).

P PEP III poses formidable logistic and scientific challenges. It spans extremes in terms of existing data.

In many parts of Western and Central Europe the need to coordinate and assimilate the results already available from published studies is at least as urgent as the need for new research.

By contrast, the record of past environmental change in vast areas of Africa is poorly documented and there is an over-riding need to expand the data base through new research. This contrast is mirrored in problems of access and logistic support for field and laboratory research in many African countries. There are also stark contrasts in the types of natural archives available for study along the full length of the transect. In the north, high resolution records, for the Holocene at least, exist in lake sediments, tree rings, peat and documentary records. In many arid and semi-arid regions on either side of the humid tropics, ground-water and discontinuous sedimentary archives are the main sources of data, but they provide a much lower resolution record and one that often fails to bring the paleo-record up to the present day. On the other hand, the lands south of the limit of the last glaciation provide quantitative evidence for the nature of lower latitude climates in glacial times and these are of outstanding significance in climate model development and validation. Moreover, the Sahara and Sahel regions provide some of the world's most dramatic evidence for massive hydrological fluctuations during the Holocene. This forms a vital antithesis to the polar perspective of a relatively stable Holocene climate. The significance of the evidence for major hydrological fluctuations in much of Africa is hightened by the vulnerability of ecosystems and human populations in the region.

Even within Europe, especially in the Mediterranean area where it is often difficult to disentangle human impacts from responses to climatic change, there is an urgent need to reconstruct the antecedents of fragile, stressed ecosystems.

The Workshop held in Bierville in September 1996 was a major landmark in responding to the challenges posed by PEP III. The present Newsletter highlights the outcome of this Meeting and subsequent progress.

The IMAGES programme is co-sponsored by PAGES and SCOR, the Standing Committee on Oceanic Research.

IMAGES is now at the stage where its Science Plan has been published and its organizational structure approved by both SCOR and IGBP. Results of the highest quality from the first IMAGES cruise have already been demonstrated, notably at the Fall AGU Meeting in San Francisco last December. A crucial aspect of the IMAGES strategy is to target high resolution records from parts of the world's oceans of particular significance in terms of energy transfer, productivity or linkage to other aspects of the earth system. Emphases on multiproxy records and on developing connections between marine and terrestrial sequences are of vital importance and here IMAGES is also leading the way and setting new standards for these endeavours.

The present Newsletter profiles some of the recent achievements of IMAGES and outlines its plans for the near future. linkages within and outside the PAGES framework, key scientific questions for the PEP III community as a whole, the potential contribution of specific regions and archives to PEP III and the future organization of PEP III activities at regional and national scale. The posters illustrated scientific results from specific sites and methods.

Several working-group meetings were held from which emerged a series of recommendations. Some of these are summarised briefly in the text that follows and they will form the main thrust of the final Workshop Report. The text and illustrative material that follows is selective rather than comprehensive. It is intended to give a flavour of the Meeting, to introduce the PAGES community as a whole to some of the challenges and opportunities that lie ahead for PEP III scientists and to foreshadow the Workshop Report being prepared for publication later this year.

\section{- Time Stream I studies in PEP III}

The report from this group recognized at the outset the desirability of high temporal resolution: seasonal wherever possible, though many valuable records will not achieve better than decadal resolution and some significantly less. Several methodological themes were emphasized, notably:

- the need to determine and make clear the true resolving power of any given archive and the extent to which this may have varied through time,

- the vital role of chronology and the need to adopt a multiple approach to developing the time frame in situations where absolute chronology is not available

- the need for replication of data with a view to reducing noise and revealing clearer records of underlying forcing mechanisms

- the essential role of calibration, in the time domain wherever possible, in order to reduce reliance on spatially derived relationships

- the strong desirability of placing realistic confidence limits on paleoclimate reconstructions

- the problems posed by reliance on the recent period of maximum human impact for calibration of paleodata against modern instrumental records

Emphasis was also placed on the potential importance of hitherto under-utilized archaeological data, especially from sites and regions that can provide high resolution records and good chronologies. This suggestion was further amplified in plenary session with special reference to the tufa deposits of the Kharga Oasis (Egypt) and the region of the Egyptian Sahara and the Nile Valley. 


\section{- Subsurface waters as Archives of paleoclimate}

The working group report and individual papers highlight the importance of subsurface waters as archives over major parts of the PEP III Transect. Despite their relatively poor temporal and spatial resolution and inevitable uncertainties in chonological control, noble gas and stable isotope records from the saturated zone, notably from confined aquifers, have been used to provide vital quantitative data for testing GCM reconstructions of past climate, especially for the Last Glacial Maximum. There is also a strong possibility that chlorine profiles from the unsaturated zone may provide important paleohydrological records in cases where the essential criteria are met. These criteria relate to the depth of the unsaturated zone between root layer and capillary fringe, the moisture content of the unsaturated zone, virtual absence of mixing of waters and a reasonably constant input of chlorine over time. The main overall conclusion of the group was to re-emphasize the special importance of subsurface water studies in large parts of the Transect where few other reliable archives exist. The formation of a Subsurface Water Working group will ensure the further development of research in these areas.

\section{- PEP III and PMIP}

Presentations at the Meeting and subsequent sessions at the recent European Geophysical Society Meeting in Vienna have begun to highlight the importance of parts of the PEP III Transect within the Paleoclimate Modeling Intercomparison Project (PMIP). The primary aim of PMIP is to determine the extent to which the simulated results from AGCM's are model dependent. The main focus is on simulations for the Last Glacial Maximum (ca.21kyr BP) and the midHolocene period ca.6kyr BP. One of the most dramatic findings so far is that although there is reasonably good comparability between the output from different modeling groups for the $6 \mathrm{kyr}$ "snapshot", there are serious discrepancies between the model reconstructions and the paleodata. This is most clearly apparent for the Sahara/Sahel region where the models fail to reconstruct conditions consistent with the paleorecords of high lake levels at this time. This in turn has provided an improved basis for parameterization of the models, using more realistic terrestrial biospheric and hydrological boundary conditions for the region. The task of reconciling models and data is far from over and this single example shows how crucial data from PEP III are for making the best possible combined use of data and models to improve eventual predictive capability.

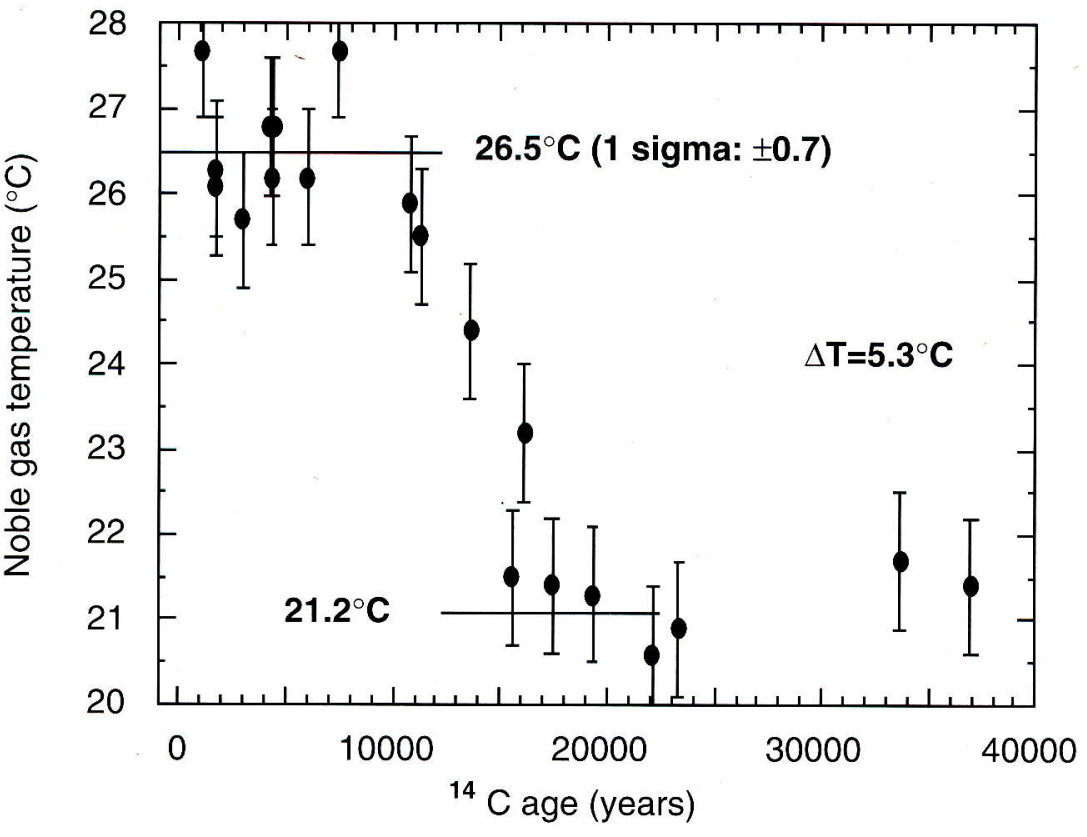

Noble gas temperature as a function of corrected radiocarbon age derived from the Stampriet aquifer, Namibia

Under favorable conditions, the concentrations of atmospheric noble gases dissolved in groundwater of confined aquifers reflect the mean annual ground temperature at the time of recharge. The record shown indicates that the mean annual temperature in Namibia was about $5.3^{\circ} \mathrm{C}$ lower during the last glacial maximum as compared to today (Stute and Talma, 1997).

(Taken from: M. Stute, M., and Talma, S. (1997) Glacial temperatures and moisture transport reoimes reconstructed from noble gases and $\delta^{18} \mathrm{O}$, Stampriet aquifer, Namibia. In: Isotope techniques in studying past and current environmental changes in the hydrosphere and the atmosphere, IAEA, Vienna, in press).

\section{- Particular archives and proxies: peat, pollen, speleothems and loess.}

Several presentations were devoted to the role of particular archives and methods in the PEP III Transect.

Peat deposits occur in N W Europe, at high altitude in tropical environments and in lake margin environments, eg as Papyrus swamps. Rainwater-fed peatlands are currently under investigation as indicators of past variations in surface wetness, hence hydrological balance. They and other types of peat contain a wealth of biological and geochemical indicators of past environmental conditions. Moreover, they often have advantages over lake sediments when it comes to extablishing chronologies by either radiocarbon or tephra analysis. Their main role will be on Stream 1 or at most mid- to late-Holocene timescales though there are exceptions. The importance of replicating results in order to distinguish climatic responses from those reflecting more site-specific effects was stressed.

Several papers illustrated the importance of pollen analytical information across the whole range of timescales and throughout the Transect. One of the key developments associated with the Meeting was the establishment of an African Pollen Data Base to complement the well established European Pollen Data Base. This opens up access to data across the whole range of PEP III and promises to make possible the much more widescale development of pollen-based paleoclimate reconstructions.

One of the most promising concepts for development within PEP III is a transect of high resolution speleothem records. Such records may be available for the whole of PEP III from $69^{\circ} \mathrm{N}$ in Arctic Norway to $34^{\circ} \mathrm{S}$ in South Africa. They provide the basis for both detailed chronologies (Th/U) and strong climate-related signatures from stable isotopes, growth laminae and organic matter. In order to exploit the limited resources of speleothem archives in a way that both maximises their value within PEP III and respects the need for conservation, the Speleothem PEP (SPEP) has been launched as a special initiative.

The paleorecord in loess and related aeolianite sediments is also of importance within PEP III. The best know loess deposits within the Transect are mostly within Eastern Europe and many of these are currently under intensive study, especially from the point of view of their magnetic properties. Although discontinuities and pedogenic overprinting make these archives less attractive than the classic Chinese loess sections, they are neverthless of considerable interest, especially where they can be closely linked to other paleoarchives. Moreover, other loess sequences, for example in France and Tunisia, 
Ancient shorelines and lacustrine sediments in many tropical Africa lakes witness climate changes undergone in tropical Africa. The hypersaline lake Asal (Diibouti) and its salt plain extended $50 \mathrm{~m}$ above its present level 3000 years ago, as seen above, and $300 \mathrm{~m}$ higher than today 8000 years ago.

(Photo: F. Gasse)

may provide comparable sequences within the Stream II timeframe. There is a need to establish a database of presently known and investigated loess sections so that regional comparisons can be made and key sites and time intervals targeted.

\section{- National and regional groups}

Alongside the thematic Working Groups, PEP III has established National and Regional Working Groups. Reports from these were presented and their importance emphasized, especially in the context of Eastern Europe. One of the most exciting regional developments is the establishment of the PAGES Regional Reseach Centre in the University of Nairobi, Kenya. This Centre is working with START to implement a modern, efficient data and information system that will more effectively link African paleoscientists with the world-wide community through electronic communications. One of the central research tasks of the PAGES RRC is its contribution to the coordination of the East African Lakes (IDEAL) programme, though it also has an important research role in relation to the GCTE Miombo Transect, paleomonsoon phenomena in Africa, the study of crater lakes and the whole wealth of paleoarchives in the region.

\section{- Data storage and management}

The Meeting also gave preliminary consideration to the issue of data storage and management. Key points that were emphasized included:

- compatibility with the World Data CentreA/ PAGES Data Base in Boulder Colorado - development of a PEP III communication node at MEDIAS FRANCE

- the need to optimize links with existing data bases such as those developed to exploit data within particular specialisms

- the desirability of creating an open and easily incremental relational data base

- the over-riding importance of broadly based community discussion and consent in the creation, control and administration of a PEP III data base.

\section{Françoise Gasse}

Laboratoire d'Hydrologie et de Géochimie Isotopique URA CNRS 723

Université de Paris $X$

91405 Orsay, France

e-mail: gasse@geol.u-psud.fr
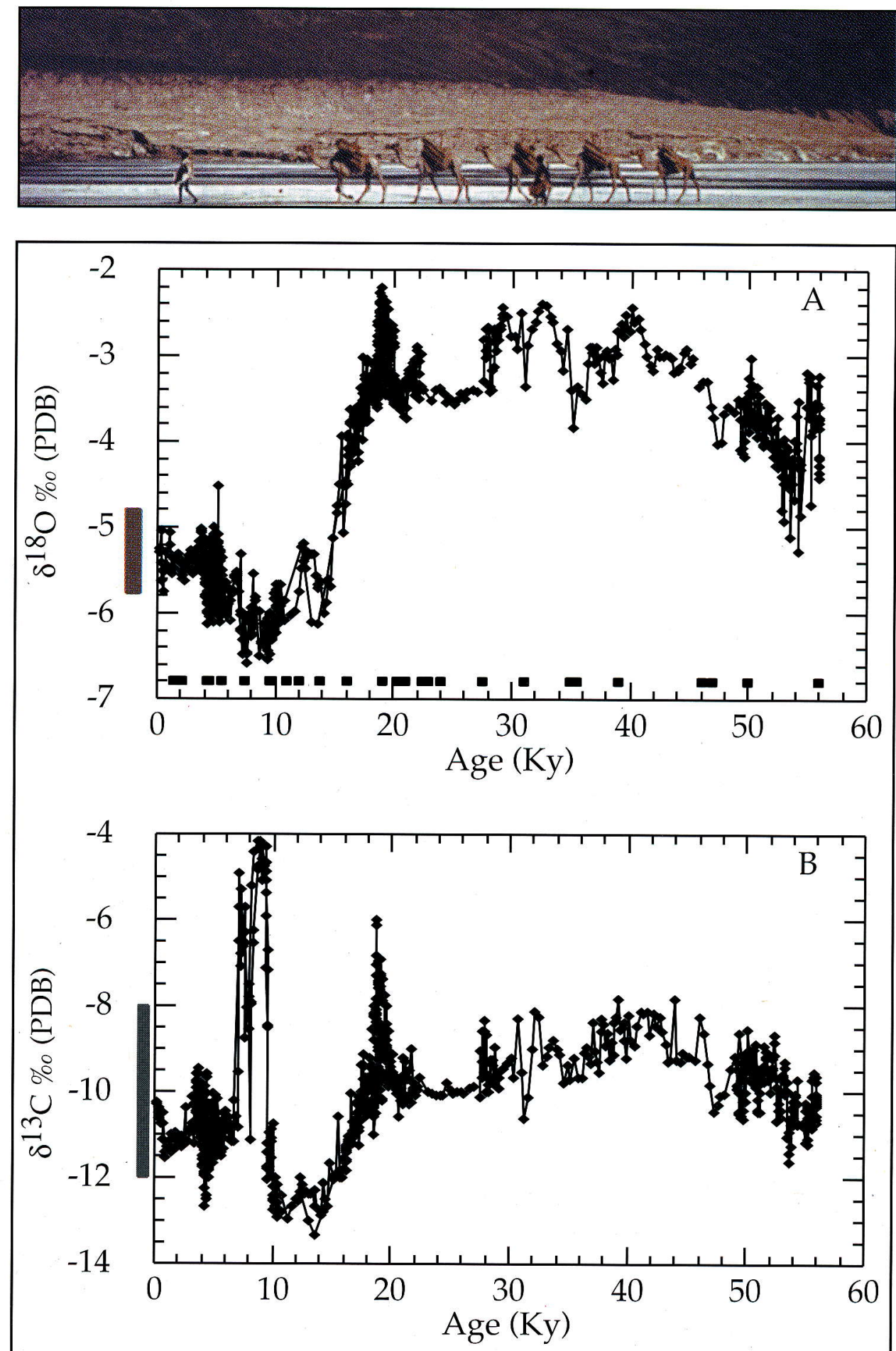

$\delta^{18} \mathrm{O}(\mathrm{A})$ and $\delta^{13} \mathrm{C}(\mathrm{B})$ variations of speleothems from the Soreq Cave (Israel) extending to $58 \mathrm{Ky}$. The squares plotted in A show the ${ }^{230} \mathrm{Th}$-U ages. The vertical bars show the present-day isotopic compositional ranges.

(Taken from Bar-Matthews M., Ayalon, A and Kaufman A. (1997) Paleoclimate evolution in the Eastern Mediterranean region during the last 58,000 yr as derived from stable isotopes of speleothems (Soreq Cave, Israel). Proceedings of the International Symposium on Isotope Techniques in the study of past and current environmental changes in the hydrosphere and the atmosphere. IAEA, Vienna, P. Murphy (Editor) In press. These diagrams present a continuous stable isotopic record obtained from cave deposits (speleothems). The studied cave (Soreq Cave) is located $60 \mathrm{~km}$ inland from the Israeli Mediterranean coast. The stable isotopic record provides a detailed insight into the climatic evolution of the late Pleistocene and Holocene, and that it is the eastern Mediterranean reflection of global climatic conditions.

The paleoclimatic interpretations of this record are given in the reference cited above, and also in: Bar-Matthews M., Ayalon, A. and Kaufman, A., 1997. Late Quaternary paleoclimate in the eastern Mediterranean region from stable isotope analysis of speleothems at Soreq Cave, Israel. Quaternary Research 47, 155-168. 


\section{6-1997 Activities of CAPE (Circum-Arctic PaleoEnvironments)}

CAPE (Circum-Arctic PaleoEnvironments), is a Project within IGBP-PAGES with a central mandate to link international and national Arctic paleo-programs, and to provide a forum for regional syntheses and modeling, particularly those tasks that cannot be easily achieved by individual investigators or even regionally-focused research teams. The emphasis of CAPE is on paleoenvironmental reconstructions covering the last 250,000 years of Earth history, concentrating on circum-arctic terrestrial environments and adjacent continental margins. The primary mechanism by which CAPE will perform its role is through a series of tightly focussed workshops that address specific topics identified by the community as key to our understanding of the role of the Arctic in the climate system.

\section{The CAPE Holocene Project}

The first task identified by CAPE was to define the spatial and temporal patterns of environmental change in the Arctic during the Holocene. With a rich and diverse set of proxy data available in a continuous, or near-continuous time series, the Holocene offers possibilities for paleoenvironmental reconstruction at a level of precision unavailable for earlier periods. The Holocene includes the interval of instrumental and written records, thus allowing a firmly-based calibration of proxy data in terms of climate variables, and it overlaps with the period of rapidly increasing $\mathrm{CO}_{2}$ content in the atmosphere, a significant feature to be evaluated when predicting future climate change.

A wide range of terrestrial and marine proxies exist as time series for the Holocene. Our goal was to synthesize these time series to characterize the Earth's surface in the Arctic at $1 \mathrm{ka}$ time slices through the Holocene. On land, reconstructions were based primarily on paleovegetation data (pollen and macrofossils) interpreted in terms of a limited number of vegetation types. Other surface characteristics include the distribution of lakes and glacier ice, and paleoshorelines. Additional terrestrial paleoenvironmental data are available less commonly from ice cores and tree rings, and diagnostic changes in isotope data in lakes, aerial plankton, diatoms, and various other faunal and floral elements. Key marine characteristics are the seasonal and permanent sea ice distribution, sea surface temperature (SST), water mass type (e.g. Polar versus Atlantic/Pacific) and dominant currents. A key
Fig. 1: CAPE Regional Subdivisions

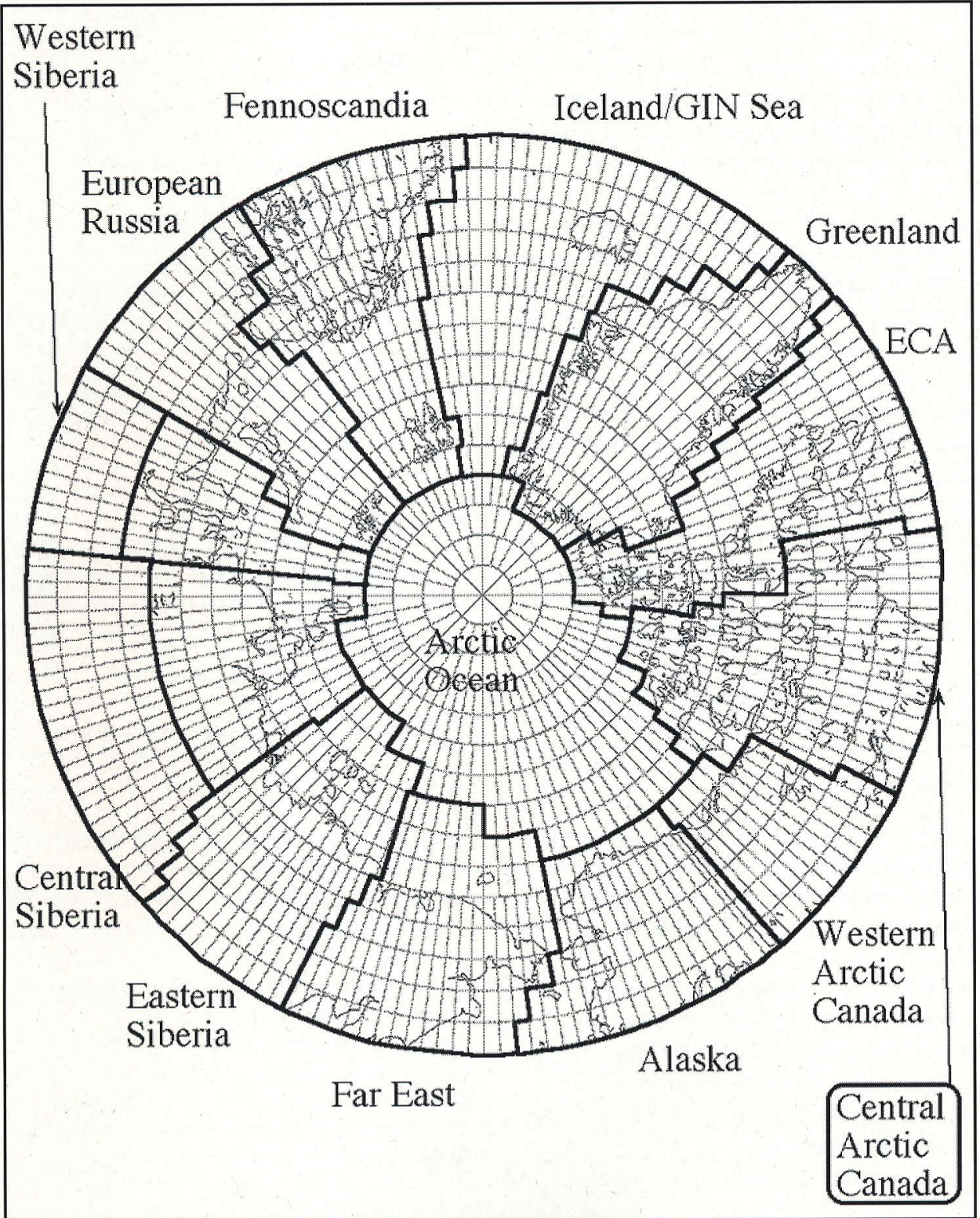

CAPE Holocene Meeting Regional Co-ordinators

\section{REGION 1: FENNSCANDIA}

Terrestrial: Sheila Hicks, U. of Oulu, Finland

Marine: Morten Hald - U. of Tromso, Norway

REGION 2: EUROPEAN ARCTIC

Terrestrial: Valeri Astakov and Andrei Andreev

Marine: Yugene Musatov

REGION 3: WEST SIBERIA

Terrestrial: Dmitri Bolshyana and Olga Borisova, Arctic \& Atlantic Institute, St. Ptersburg

Marine: Vladimir Zarhidze and Yugene Musatov,

Russian Institute of Arctic Geology, St. Petersburg, Russia

REGION 4: CENTRAL SIBERIA

Terrestrial: Hans Hubberton

Marine: Heidi Kassens

REGION 5: EASTERN SIBERIA

Terrestrial: Veteslav Markeev and Nicolai Romanoski Marine: Heidi Kassens

REGION 6: FAR EAST RUSSIA

Terrestrial: Anatolya Lochkin

Marine: Yugene Musatov and Glen Jones

REGION 7: ALASKA

Terrestrial: Linda Brubaker, U. Washington, WA, USA

Marine: Peter Barnes, USGS, Menlo Park, CA, USA

REGION 8: WESTERN CANADIAN ARCTIC Terrestrial: Les Cwynar

Marine: Steve Blasco, Geol. Survey Canada, Atlantic, Dartmouth, NS, Canada

REGION 9: CENTRAL CANADIAN ARCTIC

Terrestrial: Glen MacDonald, UCLA, CA, USA and Konrad Gajewski, U. Laval, Quebec, Canada Marine: Art Dyke, GSC Ottawa, Ottawa, Ontario, Canada and Peta Mudie, GSC Atlantic, Dartmouth, NS, Canada

REGION 10: EASTERN CANADIAN ARCTIC Terrestrial: Gifford Miller, Univ. of Coloradol INSTAAR, CO, USA

Marine: John Andrews, Univ. of Colorado/INSTAAR, CO, USA and Peta Mudie, GSC Atlantic,

Dartmouth, NS, Canada

REGION 11: GREENLAND

Terrestrial: Ole Bennike, DGU, Copenhagen, Denmark

Marine: Rudiger Stein, AWI, Bremerhaven, Germany REGION 12: ICELAND

Terrestrial: Aslaug Geirsdottir, Univ. of Iceland, Iceland

Marine: Aslaug Geirsdottir, Univ. of Iceland, Iceland 
element of CAPE is to ensure that the syntheses are data-based, with full documentation of the sources, and archiving of the primary data in one of the international paleoenvironmental databases.

\section{The Lammi Meeting}

The first meeting of the CAPE Holocene Project was held in Lammi, Finland on 4-8 April 1997. Nearly 40 scientists from Canada, Denmark, Finland, Germany, Iceland, Norway, Russia, Sweden, United Kingdom, and the United States, who are currently active in Arctic research attended the meeting. To synthesize the vast array of observational data, twelve regional working groups were established in Fall, 1996 (Fig. 1). For each region, individuals were recruited to lead the marine and terrestrial compilations. As regional compilations were completed, the data were entered into digital spreadsheets so that the regional syntheses could be compiled for the entire Arctic and compared to model simulations in real time during the meeting. At the Lammi meeting, the participants evaluated the spatial patterns of vegetation reconstructions and inferred summer temperatures in $1 \mathrm{ka}$ time slices, concentrating on the $10 \mathrm{ka}$ and $6 \mathrm{ka}$ time slices. For these times GCM summer temperature anomalies and reconstructed vegetation from the NCAR-GENESIS-EVE and/or BIOME 6000 models are available for comparison. Marine reconstructions of SST were begun, but were hampered by the limited distribution of well dated cores, the diversity of the proxies used, and the difficulty in differentiating polar water masses outside the area of Atlantic water influence. Color maps of the $6 \mathrm{ka}$ and $10 \mathrm{ka}$ GCM temperature anomalies were generated, on which the semi-quantitative estimates of temperature from nearly 400 individual sites were superimposed in a color- and size-coded scheme corresponding to the sign and magnitude of change reconstructed from the proxy data. Strong spatial patterns emerged that are by and large concordant with the GCM simulations.

\section{Accomplishments and Future Directions}

The consensus of the participants at the Lammi meeting was that major strides were achieved in the synthesis of the terrestrial data. Particularly encouraging was the development of a consensus scheme to characterize Arctic vegetation by a limited number of biomes (see Table), and the real-time visualization of these reconstructions for the entire Arctic. The marine synthesis was less complete. It was hampered by more complex, multi-proxy datasets, and less comprehensive spatial coverage. The history of sea ice variations, the single most important marine surface param-

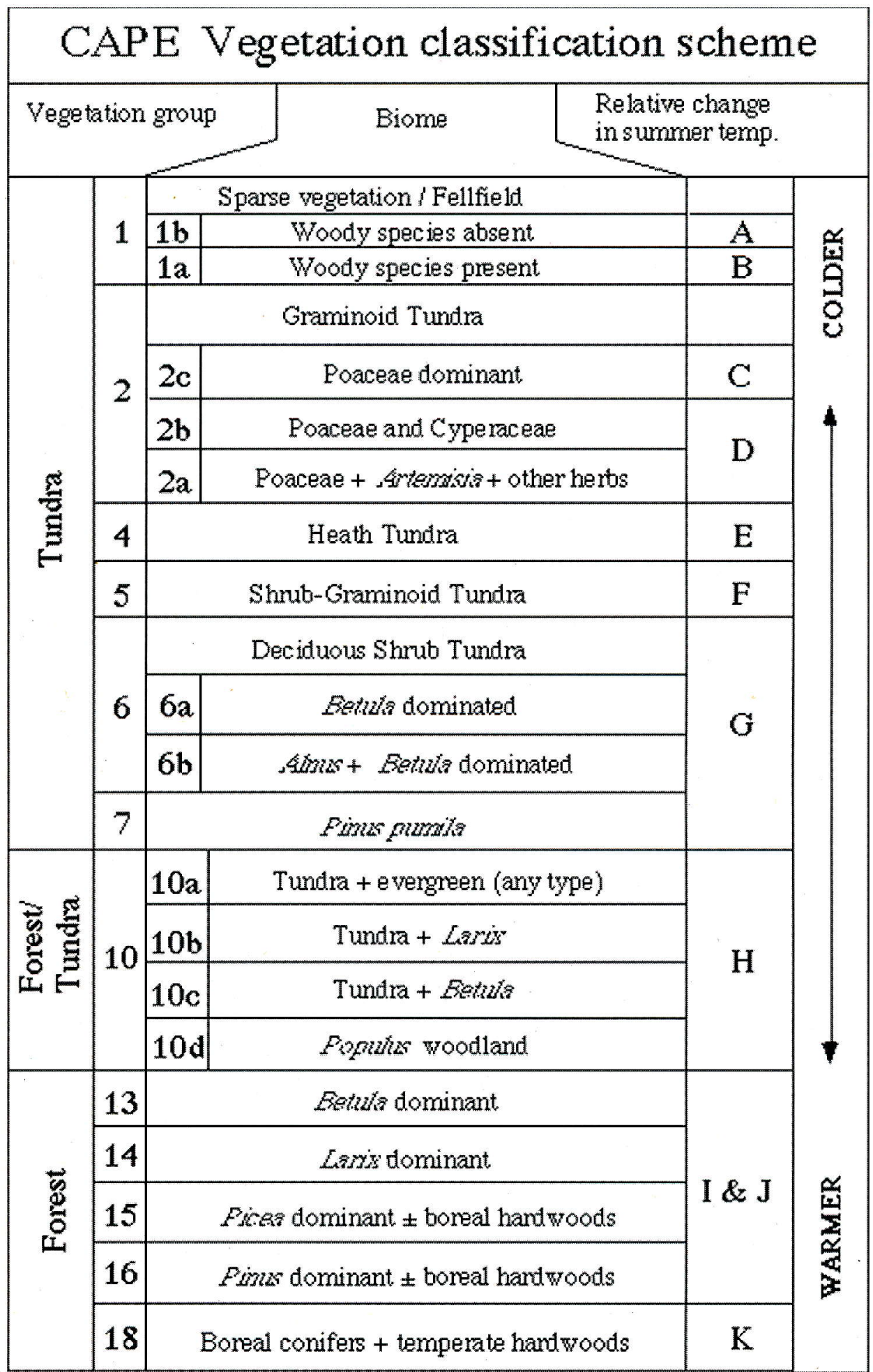

eter remains elusive, although promising data are emerging using marine dinoflagelates as sea-ice proxies. However, few high-resolution Holocene records for the Arctic have been developed.

A follow-up meeting will be held within the next 18 months, and a journal issue dedicated to the regional compilations and panArctic synthesis will be a final product.

For more detailed information, please visit the CAPE Homepage at :

http://www.ngdc.noaa.gov/paleo/cape/ TOC.htm.
Two new CAPE projects will be initiated within the next 18 months:

1) A high-resolution synthesis of the last $1 \mathrm{ka}$ to $2 \mathrm{ka}$, addressing seasonal to decadal climate change,

2) Synthesis of the Last Glacial Maximum (LGM), ca. 25ka to $10 \mathrm{ka}$.

\section{Gifford H. Miller, Anders Elverhøı}

CAPE Co-Chairs

gmiller@colorado.edu, elverhoi@geologi.uio.no SHella Hicks

Lammi Meeting Organizing Comittee Chair hicks@sveka.oulu.fi 


\section{PAGES CALENDAR}

${ }^{*}$ : Open meetings. All interested scientists are invited to attend)

*August 24-30, 1997, Krasnoyarsk, Russia Siberian Transect Workshop on "Spatial-temporal dimensions of High-Latitude Ecosystem Changes" Contact: V.A. Koptyug, Fax: +7 383235 4846; e-mail: evag@ifor.krasnoyarsk.su

*August 28-September 2, 1997, Heiligkreutz/Riedlingen, Germany

"Seventh International Symposium on Palaeolimnology" Contact: J. Merkt, Fax +49511643 3667; e-mail: merkł@gatel :bgr.d400.de

This Symposium is followed by a scientific celebration of the 80 th birthday of Herbert $E$. Wright, Jr. at Wengen, Switzerland (Sept. 8 - 11)

Contact: B. Ammann, Fax: +41 313322059

September 7-13, 1997, Johannesburg,

South Africa - Third Symposium of African Palynology Contact: Ann Cadman, University of Witwatersrand, e-mail: 106caa@cosmos.ac.za

October 23-26, 1997, Cracow, Poland

2nd European Lake Drilling Programme (ELDP)

Workshop on "European Dimension of High Resolution

Lacustrine Sediments" (upon invitation)

Contact: Carol Williams, European Science Foundation (ESF),

Phone: +33 388767145 ;

e-mail: cwilliams@esf.org

\section{November 3-7, 1997, San Damiano (near}

San Francisco), USA

"2nd International PMIP Workshop" (upon invitation)

Contact: K. E. Taylor and Sylvie Joussaume,

e-mail: syljous@asterix.saclay.cea.fr or

ktaylor@zooks.Inl.gov

*December 8-12, 1997, San Fransisco, USA

1997 AGU Fall Meeting

See especially session U02 "Late-Quaternary

Paleoclimatology of the Tropics", U04 "Climate System

History and Dynamics", U05 "The Greenland lce Sheet:

Glaciology, Geophysics and Climate", A02 "Climate

Change Detection, Altribution, and Optimal Parameter

Estimation", A05 "Aerosols and Climate",

A14 "Calibration and Validation of Climate Change

Measurements", A18 "Scientific Uncertainty in the

Assessment of Global Climate Change", $\mathrm{H} 18$ "Isotopic

Indicators of Hydrologic Response to Climate Change:

A tribute to Hans Oeschger", H19 "Use of Tracers for

Understanding Hydrological Processes"

Contact: AGU, Fax: + 12023280566

e-mail: meetinginfo@kosmos.agu.org

\section{*February 9-2, 1998, Boulder, CO, USA}

"Second Workshop on Global Paleoenvironmental Data" Contact: Robin Webb or Dave Anderson, + 303497 6160; Fax: 303-497-6513;

e-mail: danderson@ngdc.noaa.gov,

rwebb@ngdc.noaa.gov

\section{*March 16-20, 1998, Merida, Venezuela}

"PEP 1 Meeting"

Contact: Dr. Vera Markgraf, INSTAAR, University of Colorado, Boulder CO 80309 0450, USA - e-mail markgraf@spot.colorado.edu;

or check in www page: http://instaar.colorado.edu/misc/pep.html

*April 19-23, 1998, London, UK - "First PAGES Open Science Meeting", Royal Holloway University of London, UK

Contact: Frank Oldfield, PAGES CPO Switzerland, Phone: +4131312 3133; Fax: +4131312 3168; e-mail: oldfield@pageigbp.unibe.ch

* July 2-7, 1998, Perth, Australia - PEP-II Workshop in "Variability of Southern Hemisphere Climate Systems and Linkages with Northern Hemisphere Systems, on Time

Scales covering the last two Glacial Cycles" - University of Notre Dame, Fremantle

Contact: John Dodson, e-mail: johnd@sunny.gis.uwa.edu.au

*August 23-28, 1998, Lisbon, Portugal - International Conference on Paleoceanography - ICP VI

Contact: F. Abrantes, e-mail: icp6fatima@mail.telepac.pt

*May 16-23, 1998, Torshavn, Faroe Islands - "Environmental Change in Atlantic Islands"

Contact: C. Caseldine, University of Exeter, UK - Phone: +44 1392263 347; Fax: +44 1392263 342; e-mail: c.j.caseldine@exeter.ac.uk

*September 5-7, 1998, Puerto Vallarta, Mexico - 15th AMQUA Biennal Meeting on "Northern Hemispheric-Southern Hemispheric Interconnections"

Contact: Dra. Socorro Lozano Garcia; fax: +52-5-550 6644; email: amquamex@servidor.unam.mx

*August 3-1 1, 1999, Durban, South Africa - "The Environmental Background to Hominid Evolution in Africa", INQUA XV International Congress, International

Congress Centre Durban

Contact: Margaret Avery, Phone: +27 21243 330; Fax: +27 21246716 ; e-mail: mavery@samuseum.ac.za 


\section{The IMAGES ocean coring and scientific cooperation efforts}

IMAGES has been initiated to respond to the challenge of understanding the mechanisms and consequences of climatic changes using oceanic sedimentary records. Climatic mechanisms must be studied at global scale using sophisticated models based on high quality data that represent the variability of surface and deep ocean physical and chemical characteristics during key periods of recent earth history. Individual research is no longer sufficient to resolve this problem, because the acquisition of the long sediment cores needed from high sedimentation rate areas is expensive, and the proper study of such cores demands the use of multiple tools and large numbers of measurements.

IMAGES has been established by IGBP-PAGES and SCOR to meet these demands. Its major goal is to foster coordination, at the international level, of scientific programs that address the scientific goals outlined in the IMAGES «Science and Implementation Plan». Operational support, based on specific scientific proposals, is sought from national or international scientific agencies.

The following countries and associations of institutions have pledged multi-year funding starting in 1996 or 1997:

USA (NSF MESH program), France (PNEDC program), Consortium of German Institutions (Bremen Univ., Kiel Univ. GEOMAR-Kiel, AWI-Bremerhaven), Consortium of Canadian Institutions (coord. by Univ. of New Brunswick), Consortium of Universities from China, Taiwan, Great Britain (NERC), Consortium New Zealand-Australia, Norway, Portugal and South Africa. Japan will join in 1998. Proposals are in progress in Denmark, Sweden, Spain, Russia, Holland and Tunisia.

The next Scientific Committee will meet in Stockholm, August 15-17, 1997, just prior to the conference which commemorates the 50th Anniversary of the Albatross Swedish Deep-Sea Expedition (1947-1948) : "Development of Paleoceanography as a New Field of Science".

\section{IMAGES working groups, workshops, international cruises and other activities}

Several working groups, accepted in general terms by the 1996 Scientific Committee, have been or will be launched within 1997:

\section{WG1 : North Atlantic Ultra high resolution study of the variability of surface and deep water hydrology in relation with local and global climate Chair: E. Jansen (Jansen@geol.vib.no)}

Objective: Selection of sites for giant coring, during the course of a proposed 1998 or 1999 Marion Dufresne cruise. An international proposal is in preparation for giant coring with Marion Dufresne in fjords and estuaries of the Nordic and Arctic seas, with inputs from Norway, Iceland, Russia, Canada and France. The focus will be decadal variability of the last several thousand years (the Holocene).

\section{WG2: Western Pacific Warm Pool and Kuroshio WEPAMA}

Chair: Kuo-Yen Wei (weiky@cc.ntu.edu.tw) Objective: Western Pacific warm pool, western boundary currents (Kuroshio, East Australian current), exchange between marginal seas and open ocean, sea level effects, correlation between Northern and Southern Hemispheres, comparisons between marine and continental records. Preparation of a giant coring cruise and ODP drillings along the western margins of the Pacific Ocean by the year 2000.

\section{Data Handling Working Group}

Chair: D. Anderson (dma@paleosun.ngdc.noaa.gov) IMAGES consider it imperative to have a small group of people acting as a permanent source of advice (by e-mail or direct contact). Problems are encountered in all data bank systems, and there is a rapidly developing knowledge of what to do and what not to do.

\section{- Future Working Groups in preparation}

\section{Monsoon variability (with SCOR)}

Chair: P. Wang (China)

Objective: A detailed analysis of the comparative variability of the Indian and East Asian Monsoons. Report and/or Conference in preparation for future cruises and ODPlegs. To be established in 1998 if approved by SCOR.

Western Margins of the Americas, Alaska
to Chile (in close relationship to PEP 1/V.
Margraff), with SCOR, PAGES or the Inter
American Agency
Project prepared by A. Mix (mix@oce.orst.edu)
and T. Pedersen (tfp@unixg.ubc.ca)
Project to be defined in time for submission to
the next Scicom, summer 1997, for the study of
the North-South climatic connexions with
comparison of the oceanic and continental
records.

It aims at a giant coring cruise on margins and estuaries of the Western America coasts in the years 2000-2001.

Southern Ocean, with SCAR, PAGES

Proposed chairs: R. Gersunde and D. Hodell

Project to be defined in time for submission to the next Scicom, summer 1997. Aims at giant coring cruises and ODP legs in the years 1999-2001.

\section{A specific action is considered with SCAR: ANTIME}

Chair: lan Goodwin (lan.Goodwin@utas.edu.au) ANTIME aims to core or drill high sedimentation rate areas around Antarctica for the study of decadal climatic variability during the Holocene.

\section{Working group on the revaluation of the CLIMAP 18kyrBP reference sea surface temperature map}

A workshop is planned by Allan Mix and Edovard Bard as a co-organizer.

This working group has been created after a specific demand from the climate modellers (PMIP, in particular), the $18 \mathrm{kyr}$ BP reconstruction playing a crucial role for testing climate and ocean models for different climatic conditions. They need, as soon as possible, an improved data set (CD ROM, for example) with a re-evaluation of the most criticised aspects of the CLIMAP reconstruction: sea ice cover, low latitude temperature, separation of the productivity effects on the transfer function, comparison with $\mathrm{Uk}_{37}$ potential for salinity reconstruction, more precise temporal framework, with the precise definition of what is taken as the LGM (maximum ice extension, or maximum ice volume?), and relation to Heinrich events 1 and 2 which correspond to minimum temperatures in large areas of the northern hemisphere.

\section{Sediment imaging technical working group \\ Chair: F. Rack (rack@omg.unb.ca)}

The need for developing rapidly ultra high resolution studies on long sedimentary series and a very large number of cores will demand new approaches for data acquisition tools and relations with proxies. It will be necessary to quantify continuously the perturbations introduced by bioturbation and sampling; to develop secondary proxies for interpolating changes between the more quantitative proxies which need sampling of large volumes of sediments (isotopes, micropaleontological transfer functions, geochemical parameters...) The 1-dimensional continuous records obtained by tools such as the Geotek multiSensor Track represent significant progress, but are still not sufficient. Tools must now be 
developed for 2D and 3D imaging with at least millimetric resolution, and acting on a large array of physical characteristics (to multiply the number of proxies which may be independently estimated). Expensive X-Ray video digital systems, and much too primitive colour reflectance video imaging already exist.

\section{- Symposia}

Two large symposia have been organized:

\section{American Geophysical Union,}

San Francisco, USA, December 1996

"North Atlantic Variability and Global Climate

Change"

Convenors: F. Bassinot and D. Oppo

15 oral presentations and 53 posters, about 400 participants.

\section{European Union of Geosciences,}

Strasbourg, France, March 97

"Proxies in Paleoceanography and

Paleoclimatology"

Convenors: M. Sarnthein, E. Jansen, L. Labeyrie

50 oral presentations and 34 posters, about 300 participants.
The IMAGES community will participate in the 1998 London PAGES Open Science meeting, but its main rendez-vous, that year, and subsequently every 3 years, will be the:

International Conference on
Paleoceanography - ICP VI
Lisbon, Portugal, August 23 - 28, 1998
Convenor: F. Abrantes
(icp6fatima@mail.telepac.pt)
The major theme of the Conference is
"Reconstructing Ocean History-a Window
into the Future" with five major topics:
- Polar-tropical and interhemisphere
linkages
- Does the ocean cause or respond to
abrupt climatic changes?
- Biotic responses to major
paleoceanographic changes
- Past warm climates
- Innovations in monitoring ocean history

\section{- IMAGES cruises}

Three international giant coring cruises have already been organized on board the French R.V. Marion Dufresne, to demonstrate the feasibility of large scale international collaboration focused on specific paleooceanographic objectives (Fig. 1):

\section{IMAGES 1 (MD 100, May-July 95)}

Northern Atlantic and Norwegian Sea

Chief scientists: L. Labeyrie, E. Boyle, Y. Lancelot

The main objective was coring in high sedimentation rate areas ( 10 to $20 \mathrm{~cm} / \mathrm{kyr}$ ) in zones well adapted for the study of the rapid variability of the thermohaline circulation in relation to ice sheets dynamics and global climate. 22 countries and 70 scientists participated. Funding for the program came from agencies in France, Canada, Germany, the U.S. for the main participants, and Norway, U.K. and Spain as additional projects. The cruise fulfilled most of its objectives, with the collection of 43 long (to $53 \mathrm{~m}$ ), large diameter piston cores at 41 locations.

\section{IMAGES 2 (Nausicaa MD 105, Oct-Nov 96) Western and Eastern margins of South Africa}

\section{Chief scientist: P. Bertrand}

The main objectives were the history of the Indian and Atlantic Oceans connection and of

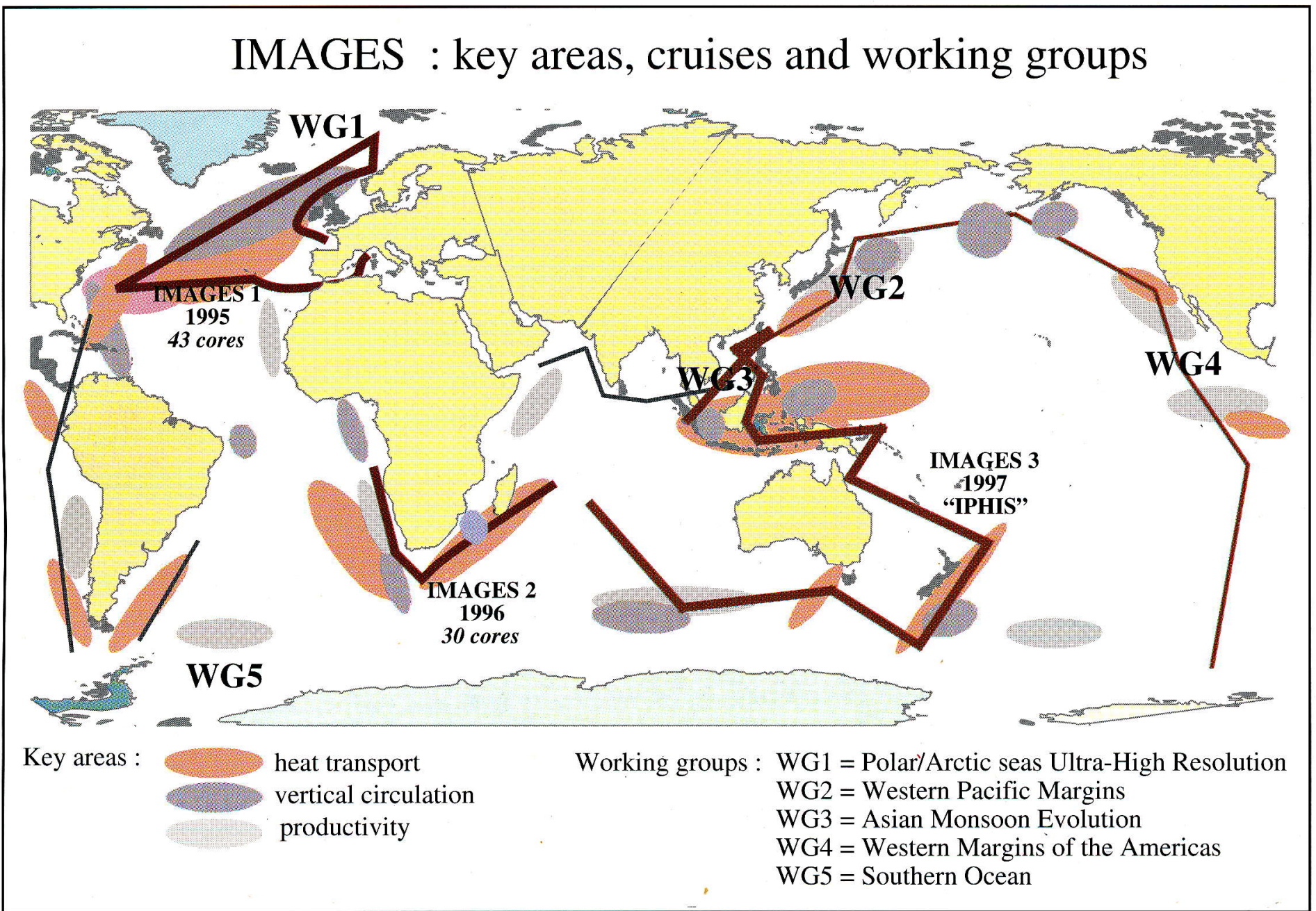


the southeastern Atlantic upwelling region over the last 300000 years.

Participation and co-sponsoring by 7 countries and university consortia: France, Germany, Taiwan, UK, South Africa, Portugal and The Netherlands.

23 giant cores (to $40 \mathrm{~m}$ ) and 19 gravity cores were collected. Sediment accumulating at rates over $15 \mathrm{~cm} / \mathrm{kyr}$ will allow temporal resolution of a few hundred years for the study of the Benguela upwelling system variability.
IMAGES 3 (IPHIS MD 106, May-July 97) Southern Ocean south of Australia and a South-North transect from South-East New Zealand to Southern China Sea

Chief scientists: J.L. Turon, E. Michel

and L. Beaufort

Main objectives: rapid climatic variability and North-South connexions; the variability of the Pacific warm pool. Delays in the preparation of the project did not permit access to Indonesian waters. That part of the cruise was therefore cancelled. Participation and co- sponsoring by 6 countries and University consortia (France, China, Taiwan, Australia, Germany, New Zealand). The cruise was still on-going at the date of the writing this text. But important successes were already achieved: several cores from the Southern Ocean cover the last 400 to 900000 years with 30-40 m of sediment; and a $16 \mathrm{~m}$ length core was sampled in the Gulf of Carpentaria (Northern Queensland, Australia) in $60 \mathrm{~m}$ water depth (on the continental shelf) over a paleo-lake from the last glacial period.

\section{Selected results obtained within the context of the IMAGES program}

Six abstracts have been selected from the AGU, EUG meetings or recent publications to illustrate progress in the description of past climatic variability using records from rapidly accumulating oceanic sediments. Two periods from the last glacial-interglacial cycles have been chosen: the Heinrich events of marine isotopic stage 3 ( 50 to $15 \mathrm{kyr} \mathrm{BP}$ ), and the last interglacial period (130 to $110 \mathrm{kyr} B P$ ).

\section{- Stratification of the photic zone in the North Aflantic during Heinrich Events recorded by planktonic microfossils}

Presented at AGU fall meeting EOS 77, F21, 1996

Quantitative studies of planktonic assemblages have been conducted in Core MD952042 (37 $\left.48^{\prime \prime} \mathrm{N}-10^{\circ} 10^{\prime \prime} \mathrm{W}\right)$ collected during the IMAGES I cruise on the Iberian Margin by $3146 \mathrm{~m}$ of water depth. The core is $37 \mathrm{~m}$ long and spans the last climatic cycle. Heinrich Events are indicated by sharp increases in magnetic susceptibility. Their stratigraphic positions in the core are in good agreement with the oxygen isotope stratigraphy. These levels are marked by synchronous, pronounced increases in the absolute and relative abundances of:

1) Florisphaera profunda (coccolith),

2) a cold morphotype of Coccolithus pelagicus (coccolith)

3) Neogloboquadrina pachyderma (planktonic foraminifera).

Coccolithus pelagicus and N. pachyderma are cold water species which migrated southward with cold waters produced by melting of ice during these events. Florisphaera profunda is a warm to temperate water species, which therefore should not cohabit with the two former species. Florisphaera profunda lives in the deepest part of the photic zone between $80 \mathrm{~m}$ and $150 \mathrm{~m}$. The fact that these three species are found together in the sediment suggests that the cold melt waters were

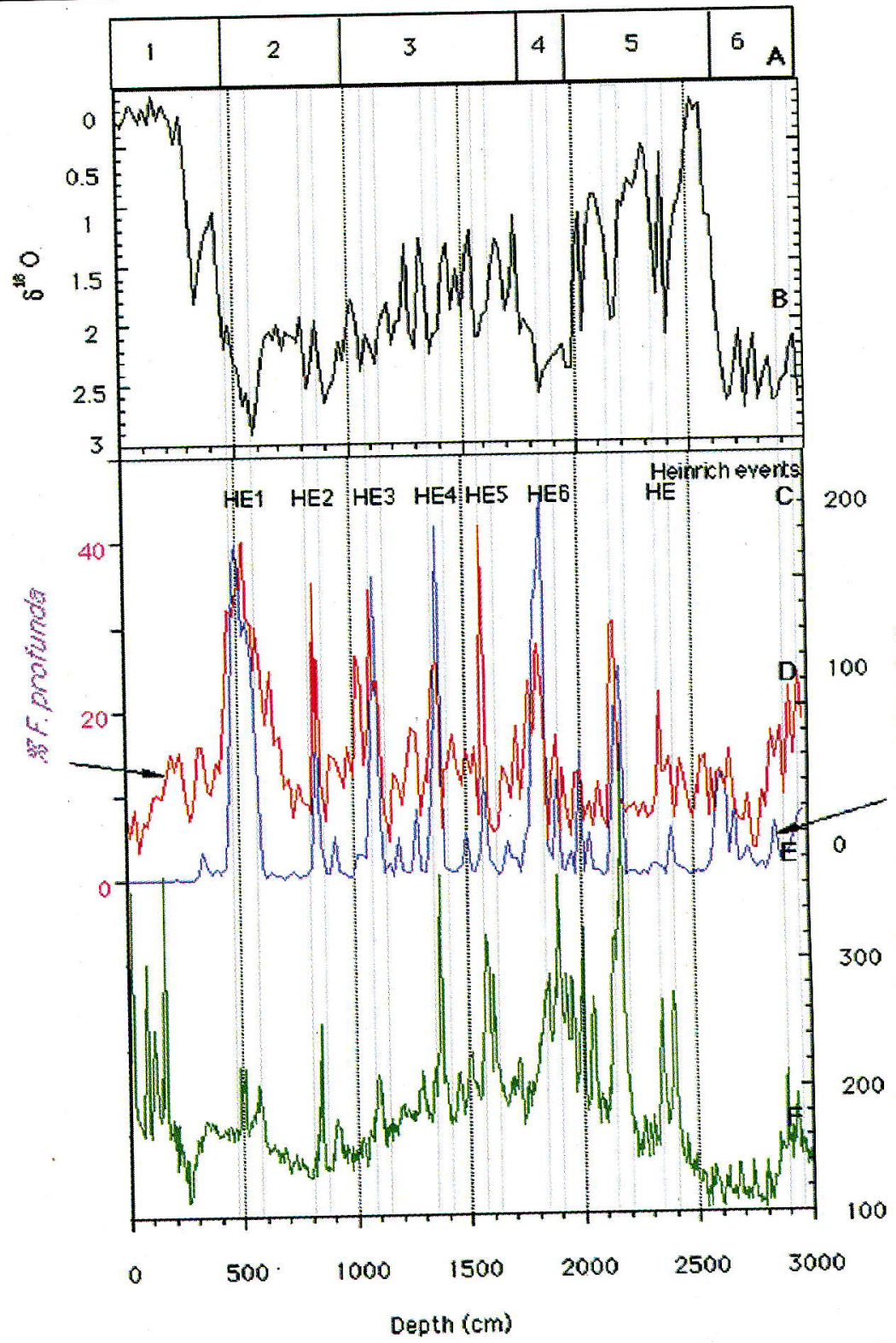

Fig. 2:

Distribution of several paleoclimatic proxies along core MD 952042 (Iberic margin)

A: Marine Isotopic Stages 1 to 6 (covering the last $150 \mathrm{kyr}$ ). B: $\delta^{18} \mathrm{O}$ of G. bulloides, a planktic foraminifera species. C: position of the Heinrich events (as traced by the sediment magnetic susceptibility). D: Relative coccolith distribution of Florisphaera profunda. E: Relative foraminiferal distribution of the polar species $N$. pachyderma s. F: Low field magnetic susceptibility 
distributed only in the upper part of the photic zone and that they were lying above warmer water in the deep photic zone. A strong inverse thermocline was thus present in the photic zone during the Heinrich Events producing a decrease in primary productivity. Our results indicate that thick tongues of melt waters reached a latitude of $37^{\circ} \mathrm{N}$ during Heinrich events in the North Atlantic.

\section{Bouldoire, L. Beaufort, O. Cayre, E. Vincent, Y. LANCELOT \\ LGQ-CNRS, CEREGE \\ 13545 Aix-en-Provence, France e-mail: beaufort@arbois.cerege.fr \\ NJ Shackleton}

Godwin Laboratory, University of Cambridge, ŮK

\section{- Glacial to Recent changes in the flow rates of deep water masses in the North- East Aflantic}

Based on a presentation at EUG Strasbourg Abst. suppl. 1, Terra Nova 9, 611, 1997

Relative flow speeds of major water in the N.E. Atlantic, have been inferred via the "sortable silt" grainsize proxy (McCave et al, 1995). Given the conclusion of Le Grand and Wunsch (1995) that isotopic tracer data at the LGM are consistent with both modern flow rates and a circulation rate of half the modern NADW flux, and that "the central need is for a data type capable of setting the overall rates of water movement", the type of data given here are of unique potential significance.

Records from 12 sites in the Iceland, Rockall and Porcupine basins of the North East Atlantic, back to at least late stage 3 and in some cases stage 6 have been studied. The water masses involved are characterised as Lower Deep Water (LDW, southern source), Lower North Atlantic Deep Water (LNADW, probable Norwegian Sea source), and Intermediate Water (IW, formed by cooling south of the Greenland-Scotland Ridge similar to modern Labrador Sea Water). Water mass designation is based on published $\delta^{13} \mathrm{C}$ and cadmium data. IW on Bjorn Drift south of Iceland shows a striking increase in speed during isotopic stage 2 with lower flow speeds in stage 3 (back to $45 \mathrm{ka}$ ) similar to those from $14 \mathrm{ka}$ to present. On the flanks of Rockall Bank this water flows rapidly until the end of the Younger Dryas, then slows. This is believed to be due to an increased formation rate of IW during the LGM. Winnowed coarse silt bands in stage 2 in Rockall Trough suggests glacial IW formation in Northern Rockall Trough. The most probable candidate for glacial LNADW is found at $2350 \mathrm{~m}$ on northern Gardar Drift in the Iceland basin. This shows high speed in stage $5 \mathrm{e}$, variable speeds with maxima about the same as modern values during later stage
5 , and stages 4 and 3 , and a pronounced decrease between 28 and $18 \mathrm{ka}$ in stage 2 . LDW flow speed is spatially variable. It is at a minimum during the LGM along the Celtic Sea continental margin and in the South Rockall Gap. However in the southern part of the Iceland Basin, and especially in the Charlie Gibbs Fracture Zone, the stage 2 flow was at maximum, declining through most of the Holocene. The slow flow in most places (except CGFZ) during the LGM suggests a generally sluggish deep ocean of LDW overlain by vigourous intermediate water. This supports the second scenario of Le Grand and Wunsch.

\section{Full references from the author:}

I.N. McCave (mocave@esc.cam.Ac.uk)

Department of Earth Sciences,

University of Cambridge, Downing Street,

Cambridge, CB2 3EQ, United Kingdom

\section{- Rapid Climate and Ocean Change in Santa Barbara Basin, California}

Results in part presented in Nature 379: 243-246, 1996

Considerable interest exists about the nature and mechanisms of rapid global climate change and of related biospheric responses. The cores taken at Ocean Drilling Program Site 893 represent the highest resolution sedimentary record of ocean environmental and biotic changes from anywhere in the ocean over the last 160 kyrs and are providing unique opportunities to study rapid climate change.

The Santa Barbara Basin record shows strong evidence for major instability of the marine environment and ecosystem off coastal California during the late Quaternary (Kennett \& Ingram, 1995; Behl \& Kennett, 1996). This instability occurs over a range of time-scales, but is most dramatically shown in association with a sequence of 18 DansgaardOeschger $(\mathrm{D} / \mathrm{O})$ climatic oscillations that occurred during the last 80 kyrs (Behl \& Kennett, 1996). These extremely rapid and major climatic warming episodes (interstadials) were first recognized in the Greenland Ice Sheet where they have been tied to synchronous $\mathrm{CO}_{2}$ and methane fluctuations. The Santa Barbara Basin record demonstrates that sea surface temperatures increased and decreased very rapidly over 50 to 70 years, at both the initiation and termination of the interstadials, as was the case in Greenland. This similarity suggests a remarkably tight coupling between the

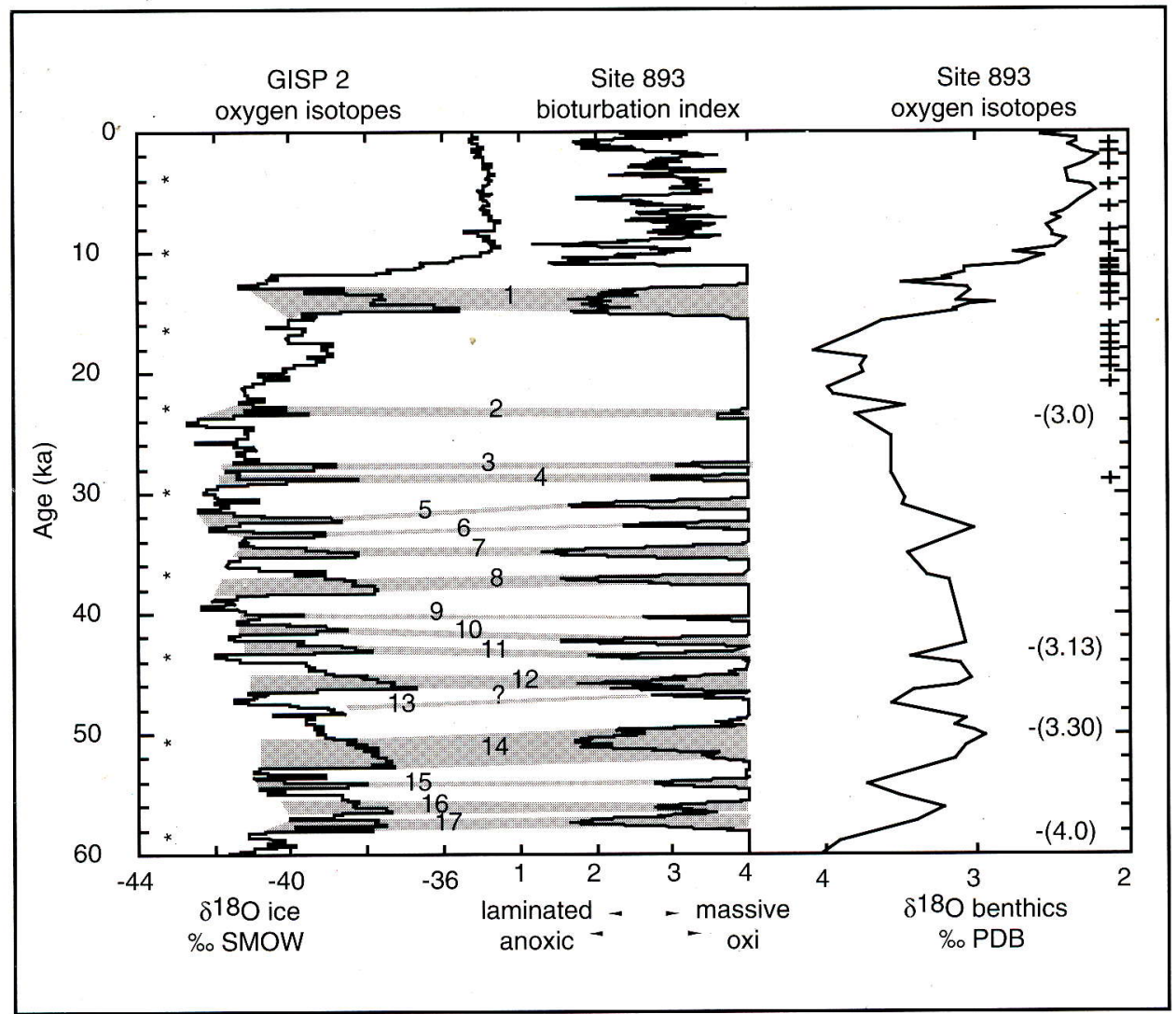

Fig. 3 (adapted from Nature 379, 244, 1996):

Comparison of ODP site 893 (Santa Barbara Basin, California) bioturbation index and benthic foraminiferal $\delta^{18} \mathrm{O}$ records with $\delta^{18} \mathrm{O}$ ice time series from GISP2

Anoxia events (laminations) are reported with the same numbering as the warm interstadials in Greenland. Chronologies for GISP2 and site 893 were independently derived. Radiocarbon age control points $(+)$ and SPECMAP data used for the site 893 age model are shown to the right. The base of each core interval in Hole $893 \mathrm{~A}$ is indicated by arrows to the left. Between 500 and 1250 yr may be missing at the two uppermost core breaks. 
atmosphere, the northern hemisphere cryosphere and hydrosphere. In Santa Barbara, oxygen isotope data indicate that seasurface temperatures initially increased up to $7^{\circ} \mathrm{C}$ in $<70$ years before stabilizing at $\sim 4^{\circ} \mathrm{C}$ warmer than before the $\mathrm{D} / \mathrm{O}$ event. An extraordinary feature of this isotopic record are the $\sim 0.5 \% \circ \delta^{18} \mathrm{O}$ overshoots occurring near the beginning of the interstadials, producing a sawtooth pattern familiar in other records of Quaternary climate change. This feature suggests the involvement of brief, strong greenhouse gas feedback mechanisms, associated with the initiation and termination of the interstadials.

The rapid climate changes are closely linked with changes in oxygenation in the basin as reflected by oscillations between laminated and non-laminated sediments and in benthic foraminiferal assemblages. These fluctuations in the benthic environment of Santa Barbara Basin were controlled by oscillations in the oxygenation of intermediate waters along the California margin. The oscillations between oxic and dysoxic conditions were also extremely rapid. Benthic foraminiferal assemblages associated with laminated sediments are dominated by low oxygen tolerant taxa including Bolivina tumida and Buliminella tenuata. Assemblages associated with non-laminated sediments typical of cooler episodes are dominated by taxa typical of oxygenated waters.

Full references available from the author:

J.P. KeNNETT (KENNET@MSI.UCSB.EDU),

I. Hendy, K. Cannariato

Department of Geological Sciences and Marine

Science Institute,

University of California,

Santa Barbara, USA

R. BEHL

Department of Geological Sciences,

California State University,

Long Beach, USA

\section{- Southern and Northern Hemisphere climatic changes: synchronous or not ?}

adapted from EUG Strasbourg Abst. suppl. 1, Terra Nova 9, 613, 1997 and Paleoceanography in press

High resolution records of planktonic foraminifera abundances and stable isotopes of benthic and planktic foraminifera in late Quaternary sediment cores from the South Atlantic have raised the question whether climate and circulation changes in the Southern Hemisphere are synchronous or offset from those in the North. This question is very important for the discussion of possible forcing and response mechanisms in the course of global climate change as discussed for example by Imbrie et al. $(1992,1993)$ with respect to the Milankovitch forcing. Recent work on climate changes on sub-Milankovitch frequencies suggests that the Southern Hemisphere surface ocean has not varied

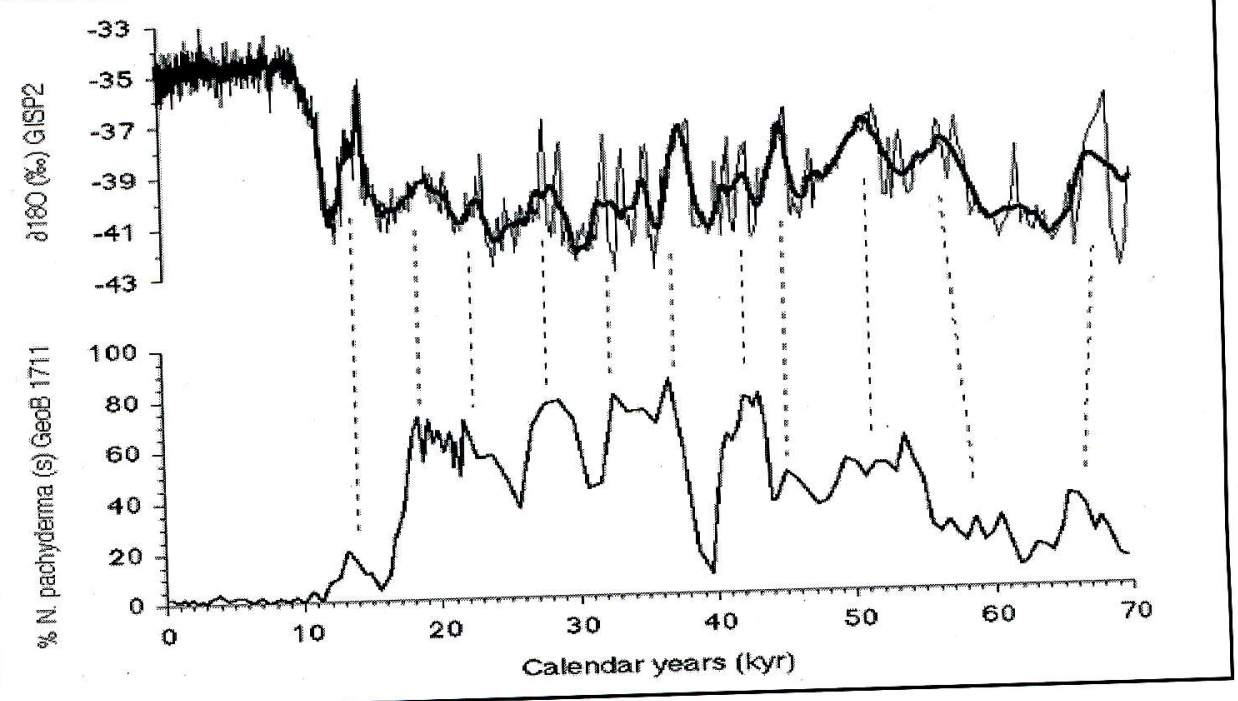

Fig. 4:

Comparison between the oxygen isotope record from Greenland GISP2 ice core and relative abundances of left-coiling Neogloboquadrina pachyderma (\% of total planktonic foraminifera) from Namibian core GeoB 1711-4 (2399' S, 12 22.6' E, 1967 m water depth)

For clarity of correlation the GISP2 oxygen isotope data has been smoothed with a 21 pt running average (thick line) with original data (thin line) superimposed. (Source of foraminiferal and ice core data, as well as ice and sediment core chronologies are reported in Little et al. 1997). Tie lines assign periods of strong trade wind induced upwelling off Namibia, as indicated by the 'PS'-Events (peaks in N. pachyderma (sin) percentages) with warm interstadials as recorded in the Greenland ice cap.

synchronously with respect to Northern Hemisphere climate fluctuations (Charles et al. 1996).

New records of the 'cold-water' planktonic foraminifera Neogloboquadrina pachyderma (sinistral) recovered from the Benguela upwelling system off Namibia reveal events of strong upwelling at subMilankovitch frequencies during the last glacial period between 70 and $10 \mathrm{kyr}$ BP. The timing of these rapid fluctuations in relative abundance of $N$. pachyderma (sin), constrained by radiocarbon datings, implies that strong wind-driven upwelling events in the South Atlantic occured simultaneously with warm periods in the Northern hemisphere, documented in Greenland ice cores. This therefore supports the finding of Charles et al. (1996). The correlation between 'PS'-events (Periods of high abundances of N. pachyderma sinistral) and climate changes known as the Dansgaard-Oeschger cycles, suggests large scale climatic teleconnections between the North Atlantic and South Atlantic surface circulation related to the trade wind systems. Based on the timing of 'PS'-events younger than 50 kyr BP relative to ice core warm interstadials, we assume that during periods of increased southeast trade wind intensity the northward transfer of subtropical surface waters enhanced the cross-equatorial heat transport. The increased supply of warm water to the Northern high latitudes via the Gulf Stream may have favoured the rapid warming of Northern Hemisphere climate on millennial time scales and increased the delivery of moisture to the higher latitudes, accelerating the growth of continental ice sheets. This scenario implies that Northern and Southern Hemisphere asynchronous behaviour at suborbital timescales relies on fluctuations in northward cross-equatorial heat transport into the North Atlantic forced by the subtropical trade wind system.

Full references from the authors:

\section{R. SCHNeider}

Fachbereich Geowissenschaften

Universität Bremen, 28334 Bremen, Germany

M. LITTLE

Geology \& Geophysics

University of Edinburgh, Edinburgh EH9 3JW

Scotland, United Kingdom

\section{- A high resolution record of marine mid- latitude $5 \mathrm{~d} / 5 \mathrm{e} / \mathrm{Termination} \mathrm{Il:}$ surface and deep water properties in the western North Atlantic.}

Derived in part from a presentation at AGU San Francisco, EOS suppl. 77, 46, F15, 1996

As part of IMAGES, a 52.7 meter sediment core was collected from the Bermuda Rise

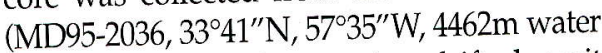
depth), a high sedimentation drift deposit where isotopic stage 5 e occurs at $43 \mathrm{~m}$ depth. We have studied stage $5 \mathrm{e}$ and the adjacent climate boundaries in detail for planktonic and benthic $\delta^{18} \mathrm{O}$, benthic $\mathrm{Cd} / \mathrm{Ca}$, planktonic foraminifera fragmentation, sediment color, and $\mathrm{Th}_{230}$-based accumulation rates. The 
Bermuda Rise $\% \mathrm{CaCO}_{3}$ record and central Greenland $\delta^{18} \mathrm{O}$ correlate in detail for interstadials during marine stages 3-5a. Significant variability is also seen throughout stage 5 , but there are no substantial fluctuations within peak $5 \mathrm{e}$. Just prior to peak $5 \mathrm{e}$, an abrupt 1-2 kyr cessation of NADW supply to this site is observed. Late in $5 \mathrm{e}$ (about $118 \mathrm{kyr} \mathrm{BP}$ ), there is a rapid shift in oceanic conditions in the western North Atlantic which has not been previously documented. Within a $2 \mathrm{~cm}$ interval, $\% \mathrm{CaCO}_{3}$ drops abruptly, and clay flux, $\mathrm{Cd} / \mathrm{Ca}$, $\%$ fragmentation and red color intensity rise abruptly. These data indicate a coincident increase both in the proportion of southern source waters and recirculation-derived clay supply. The rise in $\mathrm{Cd} / \mathrm{Ca}$, carbonate flux, and red color are short-lived, occurring over less than $8 \mathrm{~cm}$ ( 400 yrs). Immediately after this event, benthic $\delta^{18} \mathrm{O}$ begins a steady descent into marine isotope stage $5 \mathrm{~d}$.

Jess Adkins', Ed Boyle', LLoYd Keigwin², Elsa CORTIO ${ }^{3}$

1: MIT, Boston (eaboyle@mit.edu), 2: WHOI,

Whoods Hole 3: CFR, Gif-sur-Yvette, France

Fig. 5:

Details of the proxy records from core MD 952036 (Bermuda Rise) for the last interglacial period, plotted against age (kyr) : planktonic $(A)$ and benthic $(C)$ foraminiferal isotopic records; changes in $\mathrm{CaCO}_{3}$ as recorded in the gray scale; $C d / C$ a ratio in benthic foraminifera $(D)$; proportion of fragments of foraminifera (E), an index for dissolution; balance between red and yellow in the color reflectance spectra $(F)$, a proxy for the mineralogical changes between clay and carbonate content $(G)$
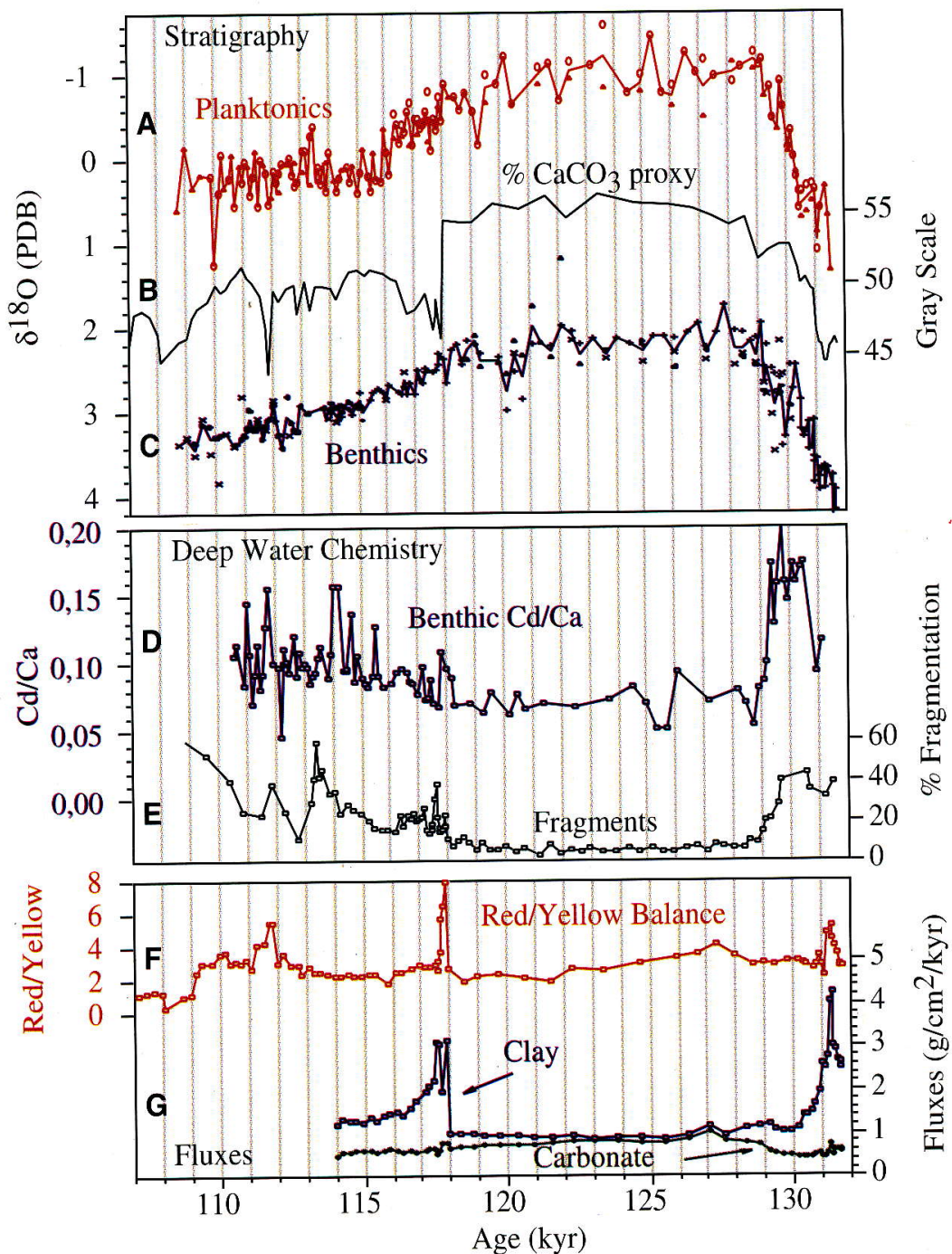

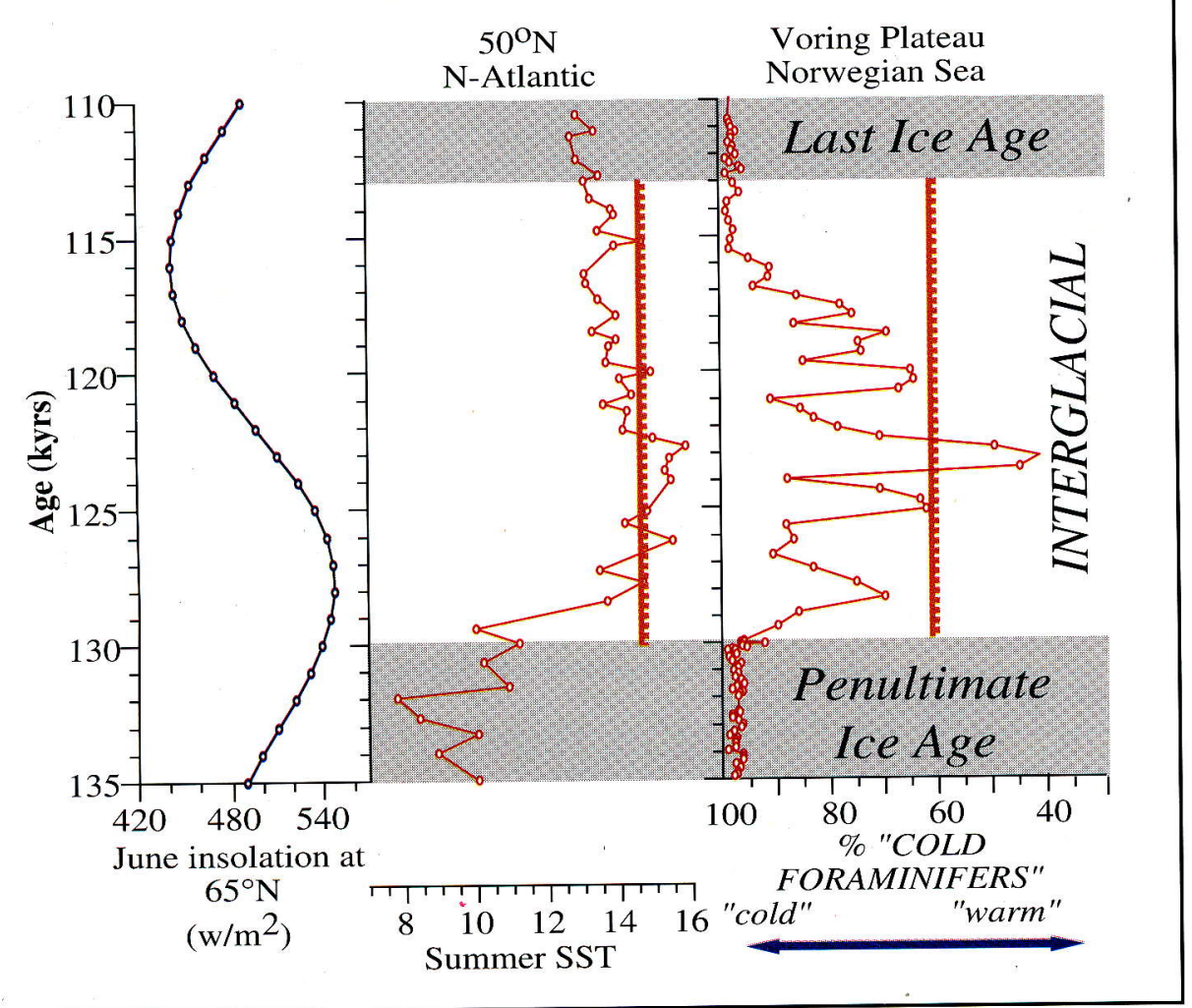

\section{- Climate variability in the last interglacial}

The Nordic Seas is an important area for water mass formation and transformation. Oceanic heat flux (The Nordic Heat Pump) strongly modifies regional climate. Convection and advection provide deep and intermediate water that circulates into the Arctic and Atlantic Oceans. It is also an area of major freshwater fluxes, strong fronts and intensive mixing. This makes the Nordic Seas potentially very sensitive to various forcings, with possible resulting strong influence on the global ocean circulation. Here we document that during the previous interglacial period SST in this region was highly variable with a sequence of high amplitude fluctuations in heat flux and circulation style. This contrasts the more stable situation of the present interglacial.

Fig. 6:

Comparison of insolation curve $\left(65^{\circ} \mathrm{N}\right.$, June, left) and proxy temperature records from core NA87-25 in the Northeast Atlantic at $54^{\circ} \mathrm{N}$ (Cortijo et al, Nature 372, 446-448) and Eastern Norwegian Sea core ODP 644 at $66^{\circ} \mathrm{N}$ (Fronval and Jansen, Nature 383, 806-810) for the last interglacial. 


\section{Ist IGBP PAGES Open Science Meeting}

\section{"Past Global Changes and Their Significance for the Future" \\ Royal Holloway University of London, UK - April 20 - 23, 1998}

The record of past global change provides many of the insights needed to understand how the global climate system operates: past, present and future. The goal of the IGBP PAGES First Open Science Meeting is to present state-of-the-art paleoenvironmental research results that help to narrow uncertainties regarding future climate and global change. The meeting will also serve to highlight the international science and data activities of the PAGES program.

The meeting will be organized around invited plenary presentations and high-profile poster sessions. The poster sessions will be focused on the recent scientific results of PAGES activities, and the plenary presentations will focus on:

1. The full range of climate system variability

2. Climatic forcing

3. Climate system processes

4. Modeling the climate system

5. Biotic responses to climate change

6. Human consequences of climate change

The Meeting will open with registration and a reception on the evening of April 19,1998, followed by the first lecture and poster sessions on April 20 from 8:30 am onwards.

The closing sessions will be during the afternoon of April 23.

Participation will be limited to 200 people. Those offering posters that are accepted for presentation will be given first priority.

The Meeting is sponsored by:

PA_ES International Geosphere-Biosphere Programme (IGBP) PAST GLOBAL CHANGES Past Global Changes (PAGES)

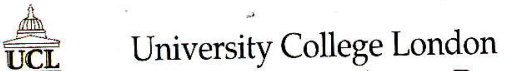

ECRC Environmental Change Research Centre

Royal Holloway University of London

CQR Centre for Quaternary Research

\section{Poster competition for young scientists from developing countries}

The Environmental Change Research Centre (UCL) is sponsoring up to 5 outstanding young scientists from Developing Countries (linked to the PAGES programme) to attend the Open Science Meeting. Applicants should indicate on the Poster Abstract Form whether they wish to be considered for this competition, and their abstracts will be judged by a review panel.

Successful applicants will be required to present their poster at the conference.

Please note that the deadline for receipt of Poster Abstracts in Bern is October 24, 1997.

A second circular will be distributed towards the end of 1997.

For all further information please contact:

Frank Oldfield, Executive Director

IGBP paGes International Project Office

Bärenplatz 2, CH 3011 , Bern, Switzerland

Phone: + 41313123133 ; FAX: + 41313123168 ; e-mail -

pages@ubeclu.unibe.ch; http://www. pages.unibe.ch/pages.html

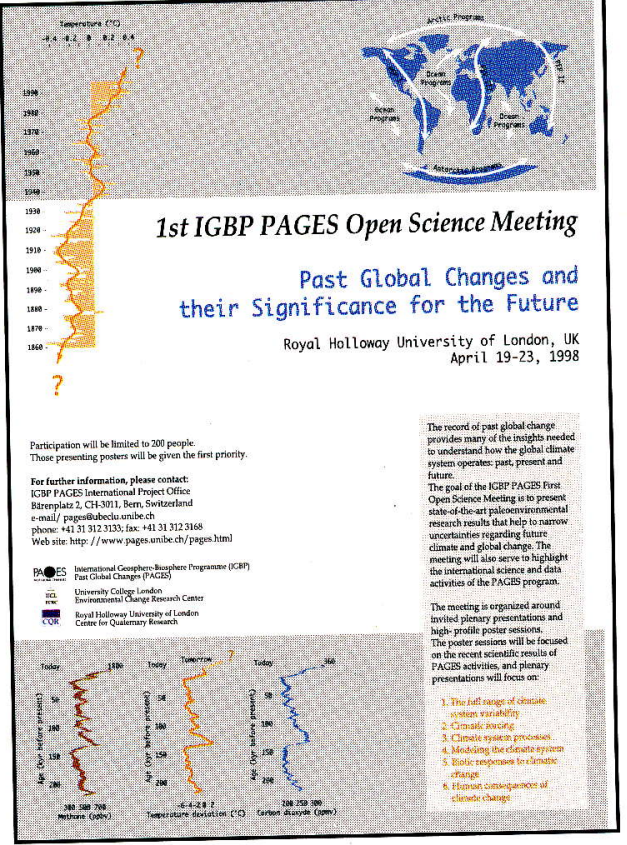

PAGES PUBLICATION LIST

Order at: PAGES International Project Office - Bärenplatz 2, CH 3011, Bern, Switzerland Order at: PAGES International Project 31c12 3168; email: pages@ubeclu.unibe.ch)

WORKSHOP REPORTS:

口 93-1 High Resolution Record of Past Climate from Monsoon Asia: The last 2000 Years and Beyond

Edited by: Raymond Bradley

93-2 An International Decade for the East African Lakes (IDEAL) Edited by: Thomas C. Johnson

प94-1 Research Protocols for PALE (Paleoclimates of Arctic Lakes and Estuaries) Issued by: PALE Steering Committee

$\square$ 94-2 INQUA/PAGES Workshop, Paleomonsoons in Africa and Surrounding Oceans: The last 2000 Years

Edited by: Stefan Kroepelin

PAGES-START Workshop, Past Global Changes in Africo

Edited by: Eric $O$. Odada

94-3 International Marine Global Change Study (IMAGES) Ścience and Implementation Plan

Issued by: IMAGES Planning Committee

95-1 THE PANASH Project, Paleodimates of the Northern and Southern Hemispheres Edited by: PANASH Leaders

95-2 GIOBAL PAIEOENVIRONMENTAL DATA, A report from the workshop sponsored by Past Global Changes (PAGES)

Edited by: David M. Anderson; Organized by: Jonathan T. Overpeck and Jonathan Pilcher

1996 The PAGES/CLIVAR Intersection. Providing the paleoclimatic perspective needed to understand climate variability and predictability Co-organized and edited by: Jean-Claude Duplessy and Jonathan Overpeck

Global Network for Isotopes in Precipitation (GNIP)

Global Network for Isotopes in
Edited by: Ulrich Schotterer

a 96-1 Himalayan Interdisciplinary Paleoclimate Project - Science and Implementation Plan

Edited by: Cameron P. Wake and Paul A. Mayewsky

96-2 Land Use and Climate Impacts on Fluvial Systems During the Period of Agriculture

Edited by: Robert J. Wasson

96-3 Climate Effects of Explosive Volcanism

Edited by: James Beget, et al.

96-4 Continental Drilling for Paleoclimate Records

Edited by: Steven M. Colman available on our Web page

IGBP REPORTS:

$\square$ NN39 Modelling the Transport and Transformation of Terrestrial Materails to Freshwate

and Caostal Ecosystems
Edited by: C.J. Vörösmarty (BAHC), R. Wasson (PAGES), J. Richey (LOICZ), 1997

PAGES NEWSLETTERS /CONTINUING PUBLICATIONS

VOL. 5 №1: April, 1997 (PEP I; PEP II; Great Barrier Reef 'climatic optimum' at 5,800 yBP)

VOL. $5 \mathrm{~N}^{\circ}$ 2: August, 1997 (PEP III; IMAGES; Last Glacial Period: air temp./ocean hydro. changes) 


\title{
The last Glacial Period: rapid changes in air temperature and ocean hydrology
}

\author{
Cortijo E., Elliot M., Vidal L., Labeyrie L., Kissel C., Grousset F.
}

Understanding the role of the ocean regarding the large amplitude climatic variability between 75 and $15 \mathrm{kyr}$ B.P. recorded in the Greenland ice cores (Dansgaard-Oeschger cycles, Dansgaard et al, 1993) has been one of the great challenges in the last few years for the paleoceanographic community within and around IMAGES (International Marine Global Change Study).

The abundance records of the polar planktic foraminifera Neogloboquadrina pachyderma left coiling in North Atlantic Ocean sediment (cores ODP609, V23-81) exhibits the same large amplitude oscillations as those observed in the Greenland ice records (Bond et al., 1993).

These results have two immediate implications:

1) open ocean sediments appear to record the century scale variability of the climate system,

2) the climate system may be reorganized significantly within a few decades to a few centuries.

This increases drastically the importance of the oceanic paleoclimatic records for understanding the causes and consequences of climatic changes both in the past and the future.

The major coolings evidenced by the polar foraminifera records correspond to large inputs of Ice Rafted Detritus (IRD) over a wide latitudinal belt $\left(40^{\circ}\right.$ to $\left.55^{\circ} \mathrm{N}\right)$. They occured at 5 to $10 \mathrm{kyr}$ interval, during the last glacial period (Broecker et al, 1992 called them "Heinrich events" after Heinrich, 1988). These iceberg discharges induced cooling by 2 to $5^{\circ} \mathrm{C}$ of sea surface temperatures associated with a strong decrease of sea surface salinity ranging from 1 to $3 \%$ (Cortijo et al, 1997).

Using the similarity of the ocean and ice records, Bond et al (1993, 95) proposed a common chronostratigraphic framework in which the Heinrich events appear to be linked to the largest coolings in the GRIP/GISP2 ice records and in which the smaller IRD inputs are synchronous with the other cold oscillations in the DansgaardOeschger cycles.

The aim of the study presented here is to contribute to the understanding of the climate system variability and the relationships between the ice and the ocean. To reach this goal, we applied a multitracer approach to different sediment cores from the North Atlantic Ocean for which high sedimentation rates made it possible to reconstruct climatic oscillations with a centennial temporal resolution. The figure shows the results obtained in two different areas: the Faeroes-Scotland ridge documented by a stack of cores ENAM93-21 and IMAGES MD95-2009 located at $62^{\circ} \mathrm{N}$ and $3^{\circ} \mathrm{W}$; and the Rockall plateau documented by core NA87-22 located at $54^{\circ} \mathrm{N}$ and $15^{\circ} \mathrm{W}$.

The chronology of the ice $\delta^{18} \mathrm{O}$ record at GRIP was constructed by counting the ice layers in the first part of the core and using an ice accumulation model where the ice layers are not visible. The sediment cores are AMS ${ }^{14} \mathrm{C}$ dated, with an error bar increasing from 50 years in surface samples to 1000 years at about $40 \mathrm{kyr}$ B.P. The chronologies of the ice and ocean records are independant.

The stacked magnetic susceptibility record from ENAM-IMAGES cores bears a noticeable resemblance to the $\delta^{18} \mathrm{O}$ of the ice at GRIP (Rasmussen et al, 1995). Each of the Dansgaard-Oeschger events between 10 and $50 \mathrm{kyr}$ is identified in the magnetic susceptiblity record of the Faieroes sediment cores (curves A and B). The lowest magnetic susceptibility values are associated with cold temperatures of the air above Greenland and, conversely, the highest values are associated with warmer air temperatures. This magnetic susceptibility record is characteristic of the whole Northern Atlantic Ocean deep water system from the Faeroes to the Southern Greenland Sea. This parameter appears to trace the variations in the size and concentration of magnetic minerals from the northern area and thus the activity of the bottom water circulation.

The different oscillations are correlated to a decrease in the $\delta^{18} \mathrm{O}$ of the planktic foraminifera, interpreted as a lowering of the surface water salinity of the North Atlantic and Southern Norwegian Sea (curve C). Based on the isotopic composition of the carbon of the benthic foraminifera Cibicides wuellerstorfi picked from the North Atlantic core NA87-22, Vidal et al, 1997, showed that reductions in deep water ventilation occurred during the largest Heinrich events (curve D), and were therefore, synchronous with sea surface drops in salinity and temperature, and reduced transport of magnetic particles by bottom currents. These $\delta^{13} \mathrm{C}$ lowerings are recorded in other North Atlantic cores but not in Norwegian Sea cores because of the absence of C. wuellerstorfi in sediments from this area.

All these different parameters point towards a strong sensitivity of deep water properties (and probably the associated thermohaline circulation) to surface salinity changes. Thus, a decrease in the conveyor belt activity would induce a high latitude atmospheric cooling.

Simple box model experiments indicate that Laurentide ice sheet internal instabilities (following the binge and purge model from McAyeal, 1994) could control such strong cold Heinrich events and the warm oscillations which follow them (Paillard and Labeyrie, 1994). The cool phase of the smaller Dansgaard-Oeschger events are also associated with IRD and surface water $\delta^{18} \mathrm{O}$ anomalies, but there is too much analytical noise to know if there is a corresponding deep water $\delta^{13} \mathrm{C}$ decrease for these low amplitude cooling events. Would they correspond to the rapid oscillations of the marine-based ice sheets around the northern Atlantic (the Fennoscandian, Iceland and Greenland ice sheets)?

\section{References}

Bond, G. W. Broecker, S. Johnsen, J. McManus, L. Labeyrie, J. Jouzel and G. Bonani 1993. Correlations between climate records from North Atlantic sediments and Greenland ice.

Nature 365: 143-147.

Bond, G. and R. Lotti 1995. Iceberg discharges into the North Atlantic on millenial time scales during the last glaciation. Science 267: 1005-1010.

Broecker, W., G. Bond, M. Klas, E. Clark and J. McManus 1992. Origin of the northern Atlantic's Heinrich events. Climate Dynamics 6: $265-273$.

Cortijo, E., L. Labeyrie., L. Vidal, M. Vautravers, M. Chapman, J.C. Duplessy, M. Elliot, M. Arnold, J.L. Turon and G. Auffret 1997, Changes in sea surface hydrology associated with Heinrich event 4 in the North Atlantic Ocean between $40^{\circ} \mathrm{N}$ and $60^{\circ} \mathrm{N}$. Earth and Planetary Science Letters 146: 29-45.

Dansgaard, W., S.J. Johnsen, H.B. Clausen, D. Dahl-Jensen, N.S. Gundestrup, C.U. Hammer, C.S. Hvidberg, J.P. Steffensen, A.E. Sveinbjörnsdottir, J. Jouzel and G. Bond 1993. Evidence for general instability of past climate from a 250-kyr ice-core record. Nature 364: 218-220.

Heinrich, H. 1988. Origin and consequences of cyclic ice-rafting in the Northeast Atlantic ocean during the past 130000 years. Quaternary Research 29: $142-152$

McAyeal, D. R. 1993. Binge/purge oscillations of the Laurentide ice sheet as a cause of the North Atlantic's Heinrich events. Paleoceanography 8: 775-784.

Paillard, D. and L. Labeyrie 1994. Role of the thermohaline circulation in the abrupt warming after Heinrich events. Nature 372: 162-164.

Rasmussen, T., E. Thomsen, T. C. E. van Weering, L. Labeyrie 1996. Rapid changes in surface and deep water conditions at the Faeroe Margin during the last 58,000 years. Paleoceanography 11: 757.771.

Vidal, L., L. Labeyrie, E. Cortijo, M. Arnold, J. C. Duplessy, E. Michel, S. Becque and T. C. E. van Weering 1997. Evidence for changes in the North Atlantic Deep Water linked to meltwater surges during the Heinrich events. Earth and Planetary Science Letters 146: 13-26. 


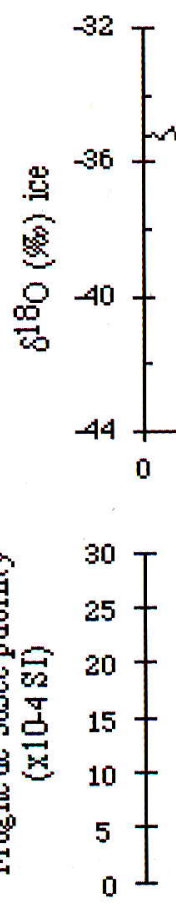

\section{The last Glacial Period:}

rapid changes in air temperature and ocean hydrology
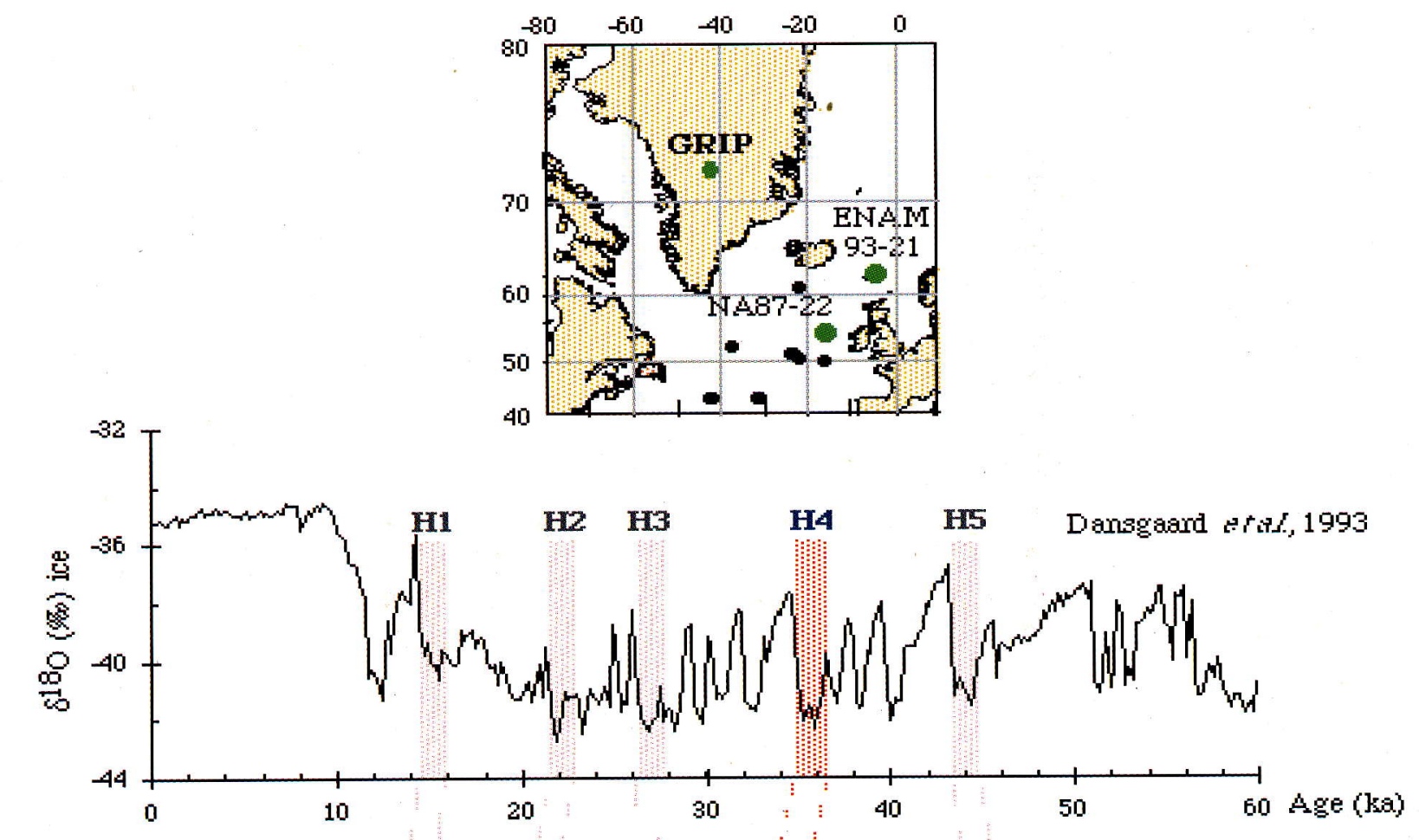

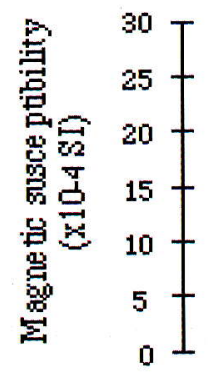

stack ENAM 93-21IM $A$ GES IM D 95-2009 $\left(62^{\circ} \mathrm{N}, 3^{*} \mathrm{~W}\right)$
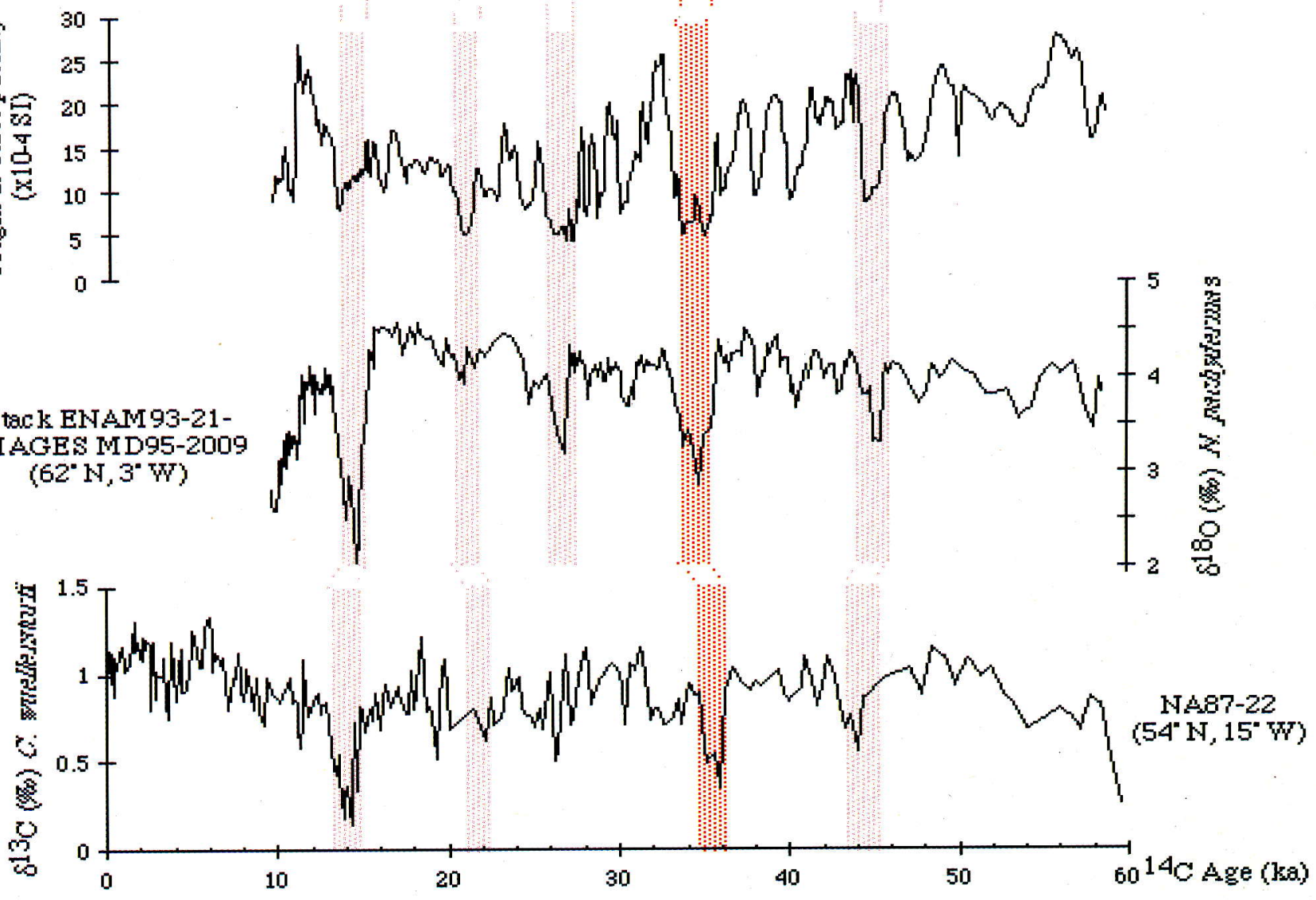